\title{
Predicting Story Comprehension of Preschool Children with and without Specific Language Impairment through Eye Movement and Executive Function
}

\author{
Deokjin Song, Dongsun Yim \\ Department of Communication Disorders, Ewha Womans University, Seoul, Korea
}

Correspondence: Dongsun Yim, PhD Department of Communication Disorders, Ewha Womans University, 52 Ewhayeodae-gil, Seodamun-gu, Seoul 03760, Korea Tel: +82-2-3277-6720

Fax: +82-2-3277-2122

E-mail: sunyim@ewha.ac.kr

Received: April 1, 2020

Revised: May 3, 2020

Accepted: May 10, 2020

This work was supported by the Ministry of Science and ICT of the Republic of Korea and the National Research Foundation of Korea (NRF2019R1A2C1007488)

\begin{abstract}
Objectives: Story comprehension is an important ability that supports not only the language skills of preschool children but also their learning skills in school age. Through three subtasks of executive function (updating, inhibition, and shifting) and eye movement, we examined the process of children's story comprehension online and offline. Also, we looked for the variable which predicts children's story comprehension. Methods: Participants were 11 children with specific language impairment (SLI) and 17 typically developing children (TD) aged 4-6 years. Group differences were compared using story comprehension (reference comprehension and inference comprehension), updating, inhibition, shifting tasks ( $n$ back, flanker, and DCCS) representing executive function and story processing using the eye tracker. Moreover, correlation analysis was conducted to find the relationship between variables, and regression analysis was used to determine which variable, executive function or eye tracker, predicts story comprehension. Results: The SLI group showed more difficulty in story comprehension and executive function than children in the TD group. Furthermore, the TD group gazed at important visual cues longer than children in the SLI group. The TD group showed a correlation between story comprehension and both the subelements of executive function and average fixation duration unlike the SLI group. Updating predicted reference comprehension and inference comprehension simultaneously in the TD group. Conclusion: It is suggested that TD children can understand stories more efficiently by using their executive function and also can distinguish areas of significance in picture books through staring at a subject for a long time to foster learning in contrast to children with SLI.
\end{abstract}

Keywords: Eye-tracking, Executive function, Story comprehension, SLI, Preschool children, Narrative
언어 이해의 단계는 단단어부터 이야기 이해까지 복잡한 과정으 로 이루어진다(Evans, 2002). 이야기를 이해하기 위해서는 고차원 적이고 복잡한 언어적 접근이 필요하며 단순히 어휘, 형태, 구문 등 의 언어적 지식뿐만 아니라 배경 지식, 개인의 경험, 인지적 능력 등 여러 가지 지식이나 경험이 필요하다(Daneman \& Carpenter, 1980). 아동의 이야기 이해 능력을 평가하는 방식 중 이야기를 듣고 질문에 답하는 방식은 가장 널리 사용되는 과제이며 실제로 일어
나는 사건과 상황을 잘 담고 있어 내용을 기억하고 이해하기에 효 율적이다(Lezak, Howieson, \& Loring, 2004). 이러한 이유로 이야 기 이해 능력은 학령전기 아동의 언어 수준을 반영하며 추후 학령 기의 언어 능력 및 학습 능력을 예측하는 요인이 될 수 있다(Bishop \& Adams, 1990; Khan et al., 2016). 구체적으로 이야기 이해는 단어 나 문장을 통해 명시적으로 드러난 내용을 이해하는 참조적 이해 력(reference comprehension)과 명시적으로 드러나진 않았지만 여 
러 개의 에피소드를 통합하여 이야기가 암시하는 메시지를 파악하 는 추론적 이해력(inference comprehension)으로 나뉜다(Desmarais, Nadeau, Trudeau, Filiatrault-Veilleux, \& Maxès-Fournier, 2013). 추론적 이해는 이야기 이해의 궁극적인 목표이며 이를 위해 서는 참조적으로 이야기를 받아들이는 것이 필요하다(Lund \& Duchan, 1993). 일반적인 발달에 따르면 4세부터 담화를 추론하는 것이 가능하지만(Filiatrault-Veilleux, Bouchard, Trudeau, \& Desmarais, 2016; van Kleeck, 2008) 단순언어장애 아동은 이야기의 참 조 및 추론적 이해에 어려움을 보인다(Botting \& Adams, 2005; Ford \& Milosky, 2008; Yim et al., 2019). Lee와 Yim (2018)의 연구 에서 두 가지 그림책을 통해 양육자의 질문에 따라 만 4-6세 어휘 발달지연 아동과 일반 아동의 이야기 이해력을 비교하였을 때, 어 휘발달지연 아동 집단이 일반 아동 집단보다 더 낮은 이야기 이해 력을 보였고 아동들이 참조적 이해보다 추론적 이해에 어려움을 보인다고 보고하였다. 또한 만 6-8세 아동의 이야기 이해 능력을 비 교한 Yun과 $\operatorname{Kim}$ (2005)의 연구에서는 참조적 이해에서 일반 아동 집단과 단순언어장애 아동 집단이 비슷한 수행력을 보였지만 추론 적 이해에서는 단순언어장애 아동의 이해력이 일반 아동뿐만 아니 라 언어 연령 일치 집단보다도 낮은 수행력을 보였다고 설명하였다.

뇌 영상 연구를 통해 단어 수준, 문장 수준, 담화 수준의 이해 능 력을 살펴본 선행연구에서는 단어 또는 문장을 이해할 때 언어 능 력에 우세성을 가진다고 알려진 좌반구가 활성화되는 반면 담화를 듣고 이해하는 과정에서는 우반구가 좌반구보다 더 활성화됐다고 보고하였다(Robertson et al., 2000; Wada, Clarke, \& Hamm, 1975). 우반구는 사회 인지 및 화용 능력에 우세성을 가져 담화 이 해에 필수적인 비유적 표현, 상황적 맥락 등의 인지적 처리를 담당 한다(Brookshire, 2014). 이처럼 가지고 있던 지식과 새로운 정보를 통합하는 이야기 이해 과정에는 언어 능력을 넘어 고차원의 처리 능력과 다양한 인지 기능이 요구된다(Kim, Sung, \& Kim, 2018; Whitely \& Colozzo, 2013). 여러 인지 기능 중 '집행기능(executive function)'은 언어와 관련한 인지 능력 중 가장 관심을 받는 영역이 며 그 둘의 관계는 오래전부터 현재까지 많은 연구를 통해 밝혀지 고 있다(Aljahlan \& Spaulding, 2019; Bus, Takacs, \& Kegel, 2015; Ebert, Rak, Slawny, \& Fogg, 2019; Ellis Weismer, Kaushanskaya, Larson, Mathée, \& Bolt, 2018; Evans, Gillam, \& Montgomery, 2018; Kapa, Plante, \& Doubleday, 2017; Roebuck, Sindberg, \& Weismer, 2018; Whitely \& Colozzo, 2013).

'집행기능'은 목표 지향적 행동을 달성하기 위해 요구되는 인지 과정을 의미하며 사고에 필요한 여러 처리 과정을 포괄한 용어이다 (Miyake et al., 2000). 집행기능을 구성하는 인지 과정에 대한 정의
는 여전히 진행 중이지만 여러 연구에서 갱신기능(updating), 억제 기능(inhibition), 전환기능(shifting)이 집행기능을 대표하는 하위 요소라는 것에 동의하고 있다(Diamond, 2013; Garon, Bryson, \& Smith, 2008; Miyake et al., 2000). 작업기억력(working memory)이 라고도 불리는 '갱신기능'은 새로운 정보가 입력될 때 그것을 저장 하고 수정된 정보를 추가하여 받아들이는 능력을 의미하고 '억제 기능은 무의미한 정보에 대한 주의를 억제하여 옳지 않은 반응을 피하는 능력을 뜻하며, '전환기능'은 과제나 자극 사이의 주의를 전 환하여 변화하는 규칙이나작업 요구에 유연하게 적응하는 능력을 의미한다(Diamond, 2013; Garon et al., 2008; Miyake et al., 2000). 위 세 가지 집행기능의 하위 요소에는 선택적 주의집중의 유지능력 (sustained selective attention)이 기저를 이루며 갱신 능력, 억제 능 력, 전환 능력 순으로 위계적 발달이 진행되지만 따로 작용될 수도 있다는 점에서 서로 분리되기도 한다(Garon et al., 2008; Miyake et al., 2000).

단순언어장애 아동들은 영역-일반적 결함(domain-general deficit)에 의해 언어뿐만 아니라 집행기능에서도 어려움을 가지며 이 에 대해 언어 능력과의 연관성을 밝히고자 현재 활발한 연구가 이 루어지고 있다(Ebert \& Kohnert, 2011; Kapa et al., 2017; Yang \& Gray, 2017; Yang \& Yim, 2018). 갱신 능력에 관한 선행연구에서는 단순언어장애 아동들이 정보를 유지하고 기억해야 하는 숫자 회 상, 단어 회상, 문장 회상 등의 과제에서 일반 아동들보다 더 낮은 수행력을 보였으며(Archibald \& Gathercole, 2006; Vugs, Hendriks, Cuperus, Knoors, \& Verhoeven, 2017) 숫자목록을 기억하고 그것을 역순으로 회상하는 숫자 역순 회상(backward digit span task)에서도 어려움이 나타났다(Archibald \& Gathercole, 2006; Kapa et al., 2017). 또한 시각적 정보를 기억하고 다시 그 공간을 회 상해야 하는 과제들에서도 일반 아동들에 비해 단순언어장애 아 동들은 낮은 수행력을 보였다(Chun \& Yim, 2017; Vugs et al., 2017). 억제 능력을 비교한 선행연구에서는 'Go/No-go task'를 통 해 비언어적 청각, 언어, 시각적 간섭 과제를 수행했을 때 만 4-5세 의 학령전기 단순언어장애 아동이 연령을 일치한 일반 아동들보다 간섭 자극에 더 영향을 많이 받았으며(Spaulding, 2010) 익숙한 소 리와추상적인 소리로 방해 자극의 난이도를 나누어 단순언어장애 아동과 일반 아동들의 억제 능력을 비교하였을 때, 단순언어장애 아동이 일반 아동들보다 두 조건의 수행력 차이를 크게 보였다 (Roebuck et al., 2018). 두 집단의 전환 능력을 비교한 선행연구에서 는 'trail making task'를 통해 1 부터 15 까지의 숫자를 순서대로 연 필로 연결하는 조건과 1 부터 8 까지의 숫자를 알파벳 순서에 맞게 연결해야 하는 조건(i.e., 1-A-2-B-3-C, etc)에서 만 7-12세 단순언어 
장애 아동과 일반 아동을 비교했을 때, 단순언어장애 아동이 더 많 은 오류를 보였으며 더 느리게 반응하였다고 보고하였다(Im-Bolter, Johnson, \& Pascual-Leone, 2006). 또한 Aljahlan과 Spaulding (2019)은 만 3-5세 아동을 대상으로 동물 소리, 동물 이름, 동물 애 니메이션 조건에서 세 가지 동물들의 소리와화면을 보여주고 동물 자극이 바뀔 때마다 버튼을 누르게 하여 아동들의 전환 능력을 알 아보고 각 조건을 혼합하여 난이도가 높아질 때 아동들의 전환 능 력이 어떻게 변화하는지 살펴보았다. 그 결과 단순언어장애 아동 들이 일반 아동들보다 과제의 난이도가 어려워질수록 오류를 자 주 보였으며 버튼을 누르는 데 걸리는 시간이 증가하였다. 학령기 어휘발달지연 아동과 일반 아동을 대상으로 집행기능의 세 가지 하위 요소와 어휘력 및 읽기 능력과 상관관계를 밝힌 선행연구에 서는 일반 아동 집단이 갱신 능력과 전환 능력에서 어휘력 및 읽기 능력과 상관관계를 보인 결과와 달리, 어휘발달지연 아동 집단에서 는 집행기능과 언어 능력의 상관을 찾을 수 없었다고 보고하였다 (Yoo \& Yim, 2018).

이야기 이해와 집행기능의 연관성을 알아본 선행연구에 따르면 작업기억력이라고도 불리는 갱신 능력이 높을수록 만 4-5세 학령 전기 아동의 담화 이해력이 높았으며(Kim et al., 2018) Whitely와 Colozzo (2013)의 연구에서는 여러 가지 갱신 과제 중 가장 어려운 갱신 과제에서 수행력이 높은 아동일수록 등장인물을 명확하게 판 단하는 경향이 있다고 밝혔다. 또한 담화가 진행될 때 등장인물의 소개, 사건의 진행, 등장인물의 재소개 과정들이 연속적으로 이어 지기 때문에 갱신 능력이 이야기 이해에 필요한 능력이라고 설명하 였다.

단순언어장애 아동과 집행기능에 관한 연구가 활발하게 이루어 지고 있으나 전반적인 집행기능과의 연관성을 살펴본 연구는 제한 적이었으며 이야기 이해력과 억제 능력, 전환 능력을 함께 살펴본 연구나 단순언어장애 아동을 대상으로 집행기능과 이야기 이해력 의 연관성을 알아본 연구는 더욱 부족하다. 단순언어장애 아동을 대상으로 상위 언어 단위인 담화 이해 능력과 집행기능과의 연관성 을 알아본다면 언어 능력과 집행기능의 보다 면밀한 관계를 파악할 수 있을 것이다.

여러 연구에서 집행기능 과제처럼 오프라인(off-line) 연구 방식 을 통해 언어발달지연이 어디에서 비롯되었는지 알아보려는 노력 이 활발히 진행되어 왔지만 최근에는 시선추적기를 이용하여 언어 처리 양상을 온라인(on-line) 방식으로 알아보는 연구가 각광받고 있다. 시선추적기법은 시간(temporal), 공간(spatial), 빈도(count) 등의 변수로 나뉘어, 눈의 움직임이 멈추는 고정(fixation), 움직임 의 변화를 의미하는 도약(sacade) 등의 측정치로 피험자의 안구 운
동을 실시간으로 분석한다(Lai et al., 2013). 또한 시선추적기법은 인지적인 활동이 일어나는 곳에 시선이 주시 된다는 눈-마음 가정 (eye-mind assumption)을 기초로 안구 운동에 반영되는 개인의 관 심을 통해 시각적 정보 처리가 이루어지는 메커니즘을 밝히고 있다 (Just \& Carpenter, 1980). 시선추적기법은 생체학적인 정보를 이용 하여 과학적으로 인간의 인지 처리 과정을 실시간으로 분석할 수 있다는 점에서 의의를 가진다(Yim et al., 2019). 난독증 아동을 대 상으로 실시한 연구에서는 난독증 아동이 글을 읽을 때 일반 아동 보다 읽었던 부분의 회귀 비율이 높았으며 짧은 단어보다 긴 단어 를 읽을 때 시선고정 횟수와 시간의 증가폭 모두 난독증 아동이 일 반 아동에 비해 유의하게 컸다고 밝혔다(Hutzler \& Wimmer, 2004). 또한 청각장애 아동을 대상으로 실시한 시선추적기 연구에 서는 청각장애 아동 집단이 정상청력 아동 집단보다 대화 시 대화 자의 얼굴을 더 오래 응시한다고 밝혔다(Sandgren, Andersson, van de Weijer, Hansson, \& Sahlén, 2014). 시선추적기 연구는 여러 장애군의 인지 처리 양상을 객관적이고 실증적인 방법으로 파악할 수 있어 임상 현장에 유용하게 적용될 수 있다.

단순언어장애 아동을 대상으로 실시한 시선추적기 연구를 살펴 보면, 18 개월의 말 늦은 아동에게 익숙한 물체에 대한 두 개의 사진 을 동시에 제시하고 그중 한 가지 목표 단어를 청각적으로 제시했 을 때 목표 사진을 바라보는 속도와 정확도가 높은 아동이 생후 30 개월이 될 동안 가속화된 어휘 성장을 보여 시각적 언어 처리 능력 이 영아의 언어 지연을 예측할 수 있다고 설명하였다(Fernald \& Marchman, 2012). 또한 18 개월의 말 늦은 아동과 일반 아동을 대 상으로 비단어 학습 능력에 대한 안구 운동을 비교하였을 때, 말 늦은 아동의 목표 자극에 대한 시선고정 시간 비율이 낮았다고 보 고하였으며(Ellis, Borovsky, Elman, \& Evans, 2015), 단순언어장애 아동은 일반 아동보다 단어 재인 과제에서 목표 그림에 관심을 두 는 고정 시간이 짧았다는 것이 밝혀졌다(McMurray, Samelson, Lee, \& Tomblin, 2010). 학령전기 단순언어장애 아동과 일반 아동 을 대상으로 비단어 빠른우연학습 중 일어나는 시각적 처리 양상 을 살펴본 선행연구에서는 애니메이션에서 비단어가 지칭하는 대 상이 나래이션과 함께 시각적으로 노출될 때 일반 아동이 단순언 어장애 아동에 비해 시선고정 시간이 더 길었다고 보고했다(Yoon \& Yim, 2019). 반면에, Yim 등(2019) 연구에서 그림책을 이용하여 어휘발달지연 아동들과 일반 아동들의 안구 운동을 비교하였을 때, 어휘발달지체 아동이 일반 아동보다 담화를 이해하는 데 어려 움을 보였으며 더 긴 평균 시선고정 시간을 보였다고 보고하였다. 이처럼 시각적 연구가 활발하게 진행되고 있지만 학령전기 아동의 이야기 이해 능력과 관련된 연구는 매우 제한적이다. 
인간의 정보 처리 시스템은 청각과 시각 채널이 단기기억 내에 동 시에 연결되어 작용할 수 있어 어휘나 문법 등의 언어적인 요소가 부족하더라도 그에 맞는 그림을 볼 수 있다면 문장을 구체화하는 데 도움이 된다(Paivio, 2008). 특히 학령전기 아동들은 대부분 초 기 문해 단계에 속해 글을 읽는 것이 익숙하지 않아 책의 내용을 이 해하기 위해서 그림 정보에 의존한다(Brookshire, Sharff, \& Moses, 2002; Luke \& Asplund, 2018). 시선추적기를 통해 학령전기 아동의 그림책 이야기 이해 과정을 실시간으로 분석하고 양상을 추적한다 면 그 과정에서 아동이 정보를 획득하는 방식, 받아들인 정보를 통 합하여 이해하는 과정의 분석이 가능할 것이다(Rayner, 1978).

본 연구에서는 학령전기 단순언어장애 아동 및 일반 아동에게 글이 없는 그림책을 보여주고 청각적 자극을 통해 이야기의 내용 을 제시할 때, 언어 장애 여부에 따라 (1) 이야기 이해 능력(참조적 이해, 추론적 이해)이 어떻게 차이 나는지 알아보고, (2) 집행기능 의 세 가지 하위 요소(갱신 능력, 억제 능력, 전환 능력)에 집단 간 어 떠한 차이를 보이는지 비교하고자 한다. 또한 (3) 시선추적기를 활 용하여 청각적인 자극이 시각적인 반응에 어떠한 영향을 주며 이 야기를 이해할 때 시선의 양상이 어떠한지 평균 시선고정 시간을 통해 집단 간 차이를 비교해보고자 한다. 이에 더해, (4) 두 집단 및 집단 별 이야기 이해력, 집행기능, 시선추적기를 활용한 이야기 처 리 과정 변수 간 상관관계를 알아보고, (5) 이야기 이해 능력을 예측 하는 변인이 무엇인지 살펴보고자 한다.

\section{연구방법}

\section{연구대상}

본 연구는 서울 및 경기 지역에 거주하는 만 4-6세의 일반 아동 17 명 $(\mathrm{M}=8, \mathrm{~F}=9)$, 생활연령을 일치한 단순언어장애 아동 11 명 $(\mathrm{M}=9, \mathrm{~F}=2)$, 총 28명이 대상자로 선정되었다.

Leonard (1998)의 기준에 근거하여 연구에 참여한 단순언어장 애 아동 집단은 (1) PRES (Kim, Sung, \& Lee, 2003)의 수용 및 표현 언어와, (2) REVT (Kim, Hong, Kim, Jang, \& Lee, 2009)의 수용 및 표현 어휘력 중 두 영역 이상이 $10 \%$ ile 미만의 수행력을 보이는 아 동으로, (3) K-ABC (Moon \& Byun, 2003)의 비언어성 지능지수가 85 (-1 SD) 이상이고, (4) 부모에 의해 사회적 상호작용의 문제, 신경 학적 손상, 청각 혹은 시각 등의 감각적 문제, 구강 구조 및 운동 능 력의 결함 등의 문제가 없다고 보고된 아동으로 선정하였다(Han \& Yim, 2018). 단, 어휘발달지연 아동과 구분하기 위하여 REVT (Kim et al., 2009)의 수용 어휘력 및 표현 어휘력의 두 영역에서만 $10 \%$ ile 미만의 수행력을 보이는 아동은 제외하였다.
Table 1. Participants' characteristics

\begin{tabular}{lrrc}
\hline & $\mathrm{TD}(\mathrm{N}=17)$ & $\mathrm{SLI}(\mathrm{N}=11)$ & $F$ \\
\hline Age $(\mathrm{mo})$ & $66.82(9.41)$ & $66.73(10.51)$ & 0.001 \\
Nonverbal IO & $111.65(6.67)$ & $105.18(11.21)$ & 3.685 \\
PRES & & & \\
$\quad$ Receptive language & $52.12(8.17)$ & $33.09(7.63)$ & $38.082^{* * *}$ \\
$\quad$ Expressive lanaguage & $44.41(7.20)$ & $31.18(8.20)$ & $20.238^{* * *}$ \\
REVT & & & \\
$\quad$ Receptive vocabulary & $68.76(9.28)$ & $42.55(22.53)$ & $18.490^{* * *}$ \\
$\quad$ Expressive vocabulary & $69.47(7.59)$ & $54.00(13.81)$ & $14.695^{* *}$ \\
\hline
\end{tabular}

Values are presented as mean (SD).

TD = typically developing children; $S$ LI = specific language impairment; PRES=Preschool Receptive-Expressive Language Scale (Kim, Sung, \& Lee, 2003); REVT=Receptive \& Expressive Vocabulary Test (Kim, Hong, Kim, Jang, \& Lee, 2009).

aKorean Kaufman Assessment Battery for Children (K-ABC; Moon \& Byun, 2003). ${ }^{*} p<.05,{ }^{* *} p<.01,{ }^{* * *} p<.001$.

일반 아동 집단의 경우 (1) PRES (Kim et al., 2003)에서 수용 및 표현 언어 능력이 모두 10\%ile 이상이며, (2) REVT (Kim et al., 2009) 의 수용 및 표현 어휘력이 모두 10\%ile 이상인 아동으로, (3) K-ABC (Moon \& Byun, 2003)의 비언어성 지능지수가 85 (-1 SD) 이상이고, (4) 부모에 의해 사회적 상호작용의 문제, 신경학적 손상, 청각 혹은 시각 등의 감각적 문제, 구강 구조 및 운동 능력의 결함 등의 문제가 없다고 보고된 아동으로 선정하였다(Han \& Yim, 2018).

생활연령, 비언어성 지능, 수용 및 표현 언어 능력, 수용 및 표현 어휘력에서 집단 간 통제가 잘 이루어졌는지 일원배치분산분석 (one-way ANOVA)을 통해 알아보았다. 그 결과, 집단 간 생활연령 $\left(F_{(1,27)}=0.001, p=.980\right)$ 과 비언어성 지능 $\left(F_{(1,27)}=3.685, p=.066\right)$ 에 는 유의한 차이가 나타나지 않았다. 수용 언어 능력 $\left(F_{(1,27)}=38.082\right.$, $p=.000)$ 과 표현 언어 능력 $\left(F_{(1,27)}=20.238, p=.000\right)$ 에는 집단 간 유 의한 차이를 보였으며 수용 어휘력 $\left(F_{(1,27)}=18.490, p=.000\right)$ 과 표현 어휘력 $\left(F_{(1,27)}=14.695, p=.001\right)$ 에서도 유의한 차이를 보였다. 이에 대한 대상자 정보는 Table 1에 제시하였다.

\section{연구도구}

이야기 이해 자료 및 이야기 이해 과제

아동의 흥미를 이끌 수 있는 애니메이션(Horrid Henry; Horrid Henry and The Tricky Treats Thief)의 일부를 이용하여 그림책 형 식의 '찰리 이야기'를 제작하였으며 전체 이야기는 총 3 분 20 초 동 안 제시되었고 총 20 장의 삽화로 구성되었다. 시각적 자극인 삽화 와 그에 맞는 청각적 자극인 내레이션이 동시에 제공되었으며 한 장 의 삽화에 대한 내레이션이 끝난 후 자동으로 삽화가 넘어가도록 구성하였다. 2 급 이상 언어재활사 자격증을 소지한 언어병리학 박 사과정 연구원 1 인, 석사과정 연구원 2 인이 이야기 이해 자료에 대 

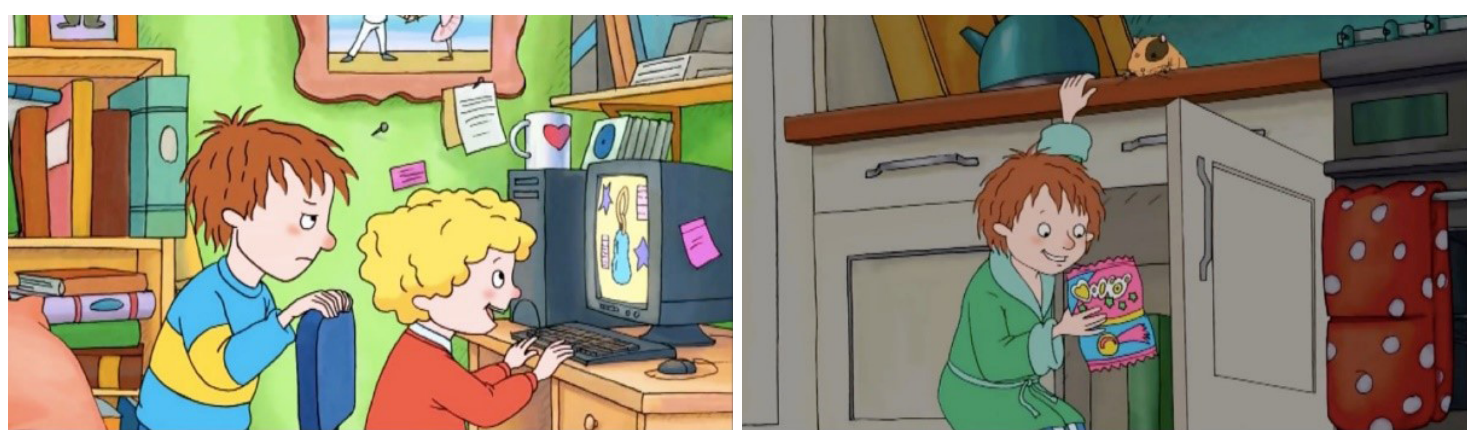

Figure 1. Examples of images in the picture book.

하여 문맥 타당도, 어휘, 구문 복잡성, 삽화 적합성에 대하여 1-5점 의 리커트 척도(Likert scale)로 내용 타당도를 검증하였으며 전체 평가 항목이 3.3 이상, 전체 평균은 4.1 로 나타나 내용이 적합한 것 으로 판단되었다. 이에 더해 언어발달장애 교육경력과 임상경력이 20 년 이상인 언어병리학과 교수 1 인과 2 급 언어재활사 자격증을 소 지한 석사과정 연구생 1 인이 내용 타당도 조사에서 나온 기타 의견 에 대해 어휘, 구문, 삽화 등의 내용을 수정하였다. 그림 예시는 Figure 1에 제시하였으며 이야기의 내용은 Appendix 1에 제시하였다.

본 연구에서는 이야기에서 명시적으로 드러나는 사건을 확인하 는 참조적 이해 질문과 전후 상황을 통해 명시적으로 나타나지 않 은 메시지를 파악하는 추론적 이해 질문으로 이야기 이해력을 살 펴보았다(Desmarais et al., 2013). 집행기능의 역할이 복잡한 문장 을 통해 효과적으로 드러날 수 있도록(Key-DeLyria \& Altmann, 2016) 이야기의 참조적 질문의 답은 이야기 자료 내에서 관형절이 포함된 문장의 목적어로 모두 만들어졌다. 이야기 이해 과제의 질 문과 답변에 관하여 2급 이상의 언어재활사 자격증을 소지한 박사 과정 연구원 1 명, 석사과정 연구원 2 명, 2 년 이상 임상 경험을 가진 언어재활사 6명, 총 9명에게 문항 타당도를 검증 받았으며 각 문항 당 1-5점의 리커트 척도를 사용하였다. 평균 4점 이상의 문항은 질 문이 적절한 것으로 판단하였고 평균 3점 이상인 문항은 제외하거 나 수정하여 각 과제당 총 10 문항을 구성하였다. 이야기 이해 과제 는 Appendix 2에 제시하였다. 이야기 자료 및 이야기 이해 과제가 적절한지 확인해보기 위하여 만 4 세 남아와 만 5 세 여아를 대상으 로 예비실험을 실시하였으며 실험 후 이야기 자료 및 이야기 이해 과제에서 아동들이 어려워한 표현이나 문항 등을 수정하였다.

과제 진행 시, 그림책 형식의 이야기 과제가 모두 제시되고 아동 의 안구 움직임이 기록된 것을 확인한 후 검사자는 이야기 이해 과 제에 따라 참조적 질문, 추론적 질문 순으로 대상자에게 이야기 이 해 질문을 제시하였다. 갱신(updating) 기능 과제

갱신 기능을 측정하기 위한 $n$-back 과제는 많은 선행연구에서 새로운 정보가 입력될 때 정보를 수정하고 조작하여 수용하는 능 력을 평가하기 위해 사용된다(Ellis Weismer et al., 2018; Ladányi \& Lukács, 2019; Whitely \& Colozzo, 2013). 본 실험에서는 $3 \times 3$ 매 트릭스(Matrix)의 한 칸에 초록색 불이 점등된 후 다음 화면의 매 트릭스에 초록색 불이 점등될 때 이전 화면과 점등 위치가 일치하 면 ‘O' 버튼을 누르고 불일치하면 'X' 버튼을 누르는 방식의 과제를 사용하였다(del Angel et al., 2015). 연속적으로 화면이 제시되며 대 상자가 버튼을 누르거나 $2000 \mathrm{~ms}$ 가 경과하면 자동으로 다음 문항 이 제시되었다. 일치조건과 비일치조건이 각각 25 문항씩 총 50 개의 문항으로 구성되었으며 아동이 버튼을 누를 때 E-prime 소프트웨 어를 통해 정확도와 반응시간이 자동으로 기록되었다. 과제의 실험 에 앞서 대상자에게 구두로 검사 방법에 대해 설명한 후 연습 문제 를 진행하였다. 연습 문제 중 대상자가 검사 방법이나 연습 문제를 이해하기 어려워하는 경우에는 아동이 과제의 규칙에 대해 정확히 이해할 수 있도록 충분히 설명해 주었으며 본 과제가 진행될 때는 어떠한 피드백도 주지 않았다. 버튼을 누른 후에는 인지적 반응을 정확히 측정하기 위해 키보드의 중간인 'space bar'에 손을 올려놓 도록 지시하였다. $n$-back 과제의 버튼은 키보드의 ' $\mathrm{V}$ ', 'N'으로 각 각 'O'와 ' $\mathrm{X}$ '를 의미하였으며 의미에 맞는 스티커를 버튼에 부착하 였다. 과제에 대한 예시는 Figure 2에 제시하였다.

\section{억제(inhibition) 기능 과제}

억제 기능을 측정하기 위한 flanker 과제(Diamond, Barnett, Thomas, \& Munro, 2007; Ellis Weismer et al., 2018)와 go/no-go 과 제(Brocki \& Bohlin, 2004; Ellis Weismer et al., 2018; Roebuck et al., 2018)는 많은 선행연구에서 사용되었다. 본 연구에서는 한 문항 당 일련의 5 개 그림을 자극으로 제시하여 다른 4 개의 돌고래가 보 는 방향(방해자극)과 상관없이 가운데 돌고래가 보는 방향(목표자 

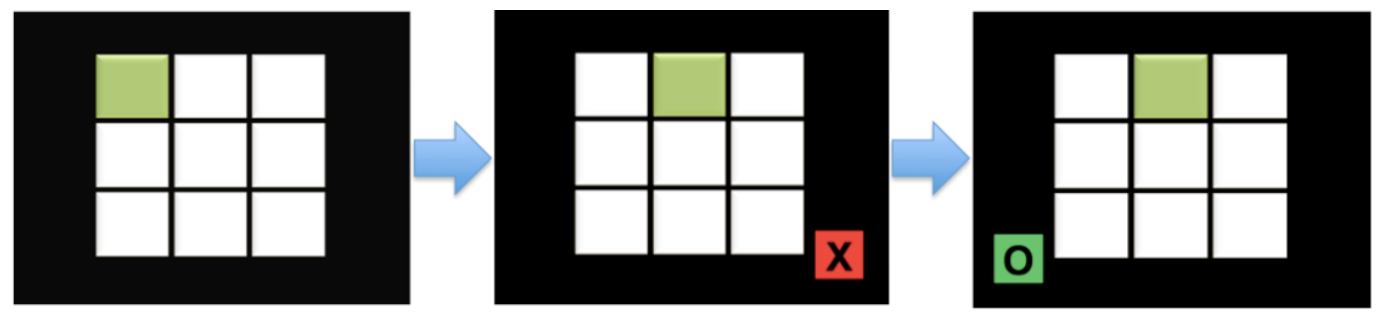

Figure 2. n-back Task.

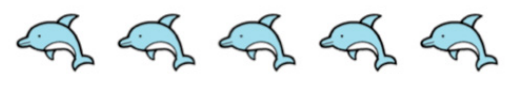

Congruent condition

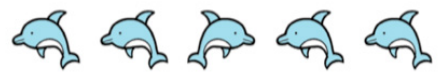

Incongruent condition

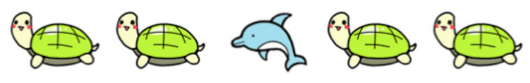

Stop condition

Figure 3. flanker Task.

극)과 일치하는 버튼을 누르는 flanker 과제 방식과 일련의 5 개의 그림 중 거북이가 제시되면 자신의 반응을 억제하여 버튼을 누르 지 않아야 하는 go/no-go 과제 방식을 혼합한 과제를 사용하였다 (Yang \& Gray, 2017). 과제는 방해자극-목표자극 일치조건 20문항, 방해자극-목표자극 불일치조건 20 문항, 정지조건 10 문항, 총 50 문 항으로 구성되었으며 아동이 버튼을 누를 때 E-prime 소프트웨어 를 통해 정확도와 반응시간이 자동으로 기록되었다. 연습 문제 중 대상자가 검사 방법이나 연습 문제를 이해하기 어려워하는 경우에 는 아동이 과제의 규칙에 대해 정확히 이해할 수 있도록 충분히 설 명해 주었으며 본 과제가 진행될 때는 어떠한 피드백도 주지 않았 다. 버튼을 누른 후에는 인지적 반응을 정확히 측정하기 위해 키보 드의 중간인 'space bar'에 손을 올려놓도록 지시하였다. flanker 과 제의 버튼은 ‘ $\leftarrow$ ' ' ' ’’ 키로 가운데 돌고래가 바라보는 방향을 의미하 였으며 방향에 맞춰 스티커를 버튼에 부착하였다. 과제에 대한 예 시는 Figure 3에 제시하였다.

\section{전환(shifting) 기능 과제}

전환 기능을 측정하기 위해 관점전환카드정렬(dimensional change card sort, DCCS; Zelazo, 2006) 과제를 실시하였다. 모든 단 계에서 빨간색 토끼와 초록색 배 그림의 보기자극 두 개와 목표자 극 한 개가 동시에 제시된다. 전환 이전 단계(색깔게임)에서는 목표 자극의 색과 두 보기자극 중 색이 일치하는 보기자극을 선택하여 해당하는 색깔의 버튼을 누르고 전환 단계(모양게임)에서는 목표 자극의 모양과 두 보기자극 중 모양이 일치하는 보기자극에 해당 하는 색깔 버튼을 누르면 된다. 마지막으로 심화 단계에서는 색깔 과 모양을 혼합한 방법을 사용하여 목표자극에 검정색 테두리가 제시되면 전환 이전 단계(색깔게임)의 규칙을 적용하고 검정 테두
리가 제시되지 않으면 전환 단계(모양게임)의 방식을 적용하였다. DCCS 과제는 전환 이전 단계 6문항, 전환 단계 6문항, 심화 단계 12 문항, 총 24 문항으로 구성되었으며 아동이 버튼을 누를 때 Eprime 소프트웨어를 통해 정확도와 반응속도가 자동으로 기록되 었다. 연습 문제 중 대상자가 검사 방법이나 연습 문제를 이해하기 어려워하는 경우에는 아동이 과제의 규칙에 대해 정확히 이해할 수 있도록 충분히 설명해 주었으며 본 과제가 진행될 때는 어떠한 피드백도 주지 않았다. 버튼을 누른 후에는 인지적 반응을 정확히 측정하기 위해 키보드의 중간인 'space bar'에 손을 올려놓도록 지 시하였다. DCCS 과제의 버튼은 키보드의 'z', '?'로 각각 빨간색과 초록색을 의미하였으며 색깔에 맞춰 스티커를 버튼에 부착하였다. 과제에 대한 예시는 Figure 4에 제시하였다.

이야기 처리 과정 과제

시각적 디스플레이는 24 인치 모니터에 맞게 $1,920 \times 1,080$ 픽셀 의 해상도로 설정하였다. 관심영역(Area of Interest, AOI)이란 검사 자가 전체 과제 내에서 시선을 추적하고 싶은 특정 영역을 설정하 는 것을 의미하며 본 과제에서는 이야기의 중심 소재로 구성되었던 참조적 질문의 답변에 일치하도록 $\mathrm{AOI}$ 를 선정하였다. $\mathrm{AOI}$ 에 맞는 각 물체나 사람은 이야기 자료 내에서 시각 및 청각적으로 모두 제 시되었으며 $\mathrm{AOI}$ 는 총 10 개로 전체 그림 20 장 중 10 장에 각각 한 개 씩 포함되었다. 시선의 움직임을 측정하기 위해 SMI (Senso Motoric Instrument)사의 'Experiment 3.5' 프로그램을 통해 과제를 설계 하였으며 샘플링 속도(sampling rate) $60 \mathrm{~Hz}$ 로 설정된 고정식 시선 추적기 REDn Scientific을 모니터(Dell, P2418HZ) 하단에 부착하 여 대상자의 안구 운동을 추적하였다. 대상자의 얼굴이 화면의 중 심에 위치하고 모니터와 대상자의 거리가 $60-70 \mathrm{~cm}$ 가 될 수 있도록 


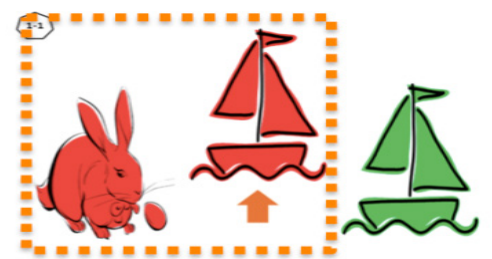

Pre-shifting (Color game)
(12)

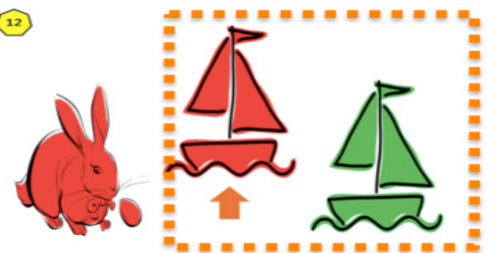

Post-shifting (Shape game)

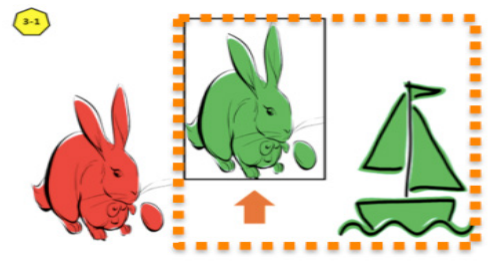

Advanced shifting (Dual)

Figure 4. Dimensional change card sort task.

간격을 조정한 후 시점조정(calibration)을 통해 5 개의 보정 포인트 에서 정확도 값이 0.6 이하인 경우에 이야기 자료를 제시하였다 (Yim et al., 2019). 시점조정은 정확한 시점 산출을 위하여 대상자 의 운동 반경, 빛의 반사, 안구 형태 등을 측정하는 과정이다(Yim et al., 2019). 대상자의 안구 움직임은 소프트웨어인 Experiment Suite Scientific Advanced를 통해 수집되었으며 검사자는 별도의 노트북에서 아동의 시선 처리 과정을 실시간으로 관찰하였다.

\section{자료분석}

이야기 이해 및 처리 과정의 분석을 위하여 검사자는 대상자의 반응을 녹음하여 모든 실험이 종료된 후 검사지에 기록하여 채점 하였다. 참조적 질문의 답은 모두 명사였으며 아동이 완전한 정반 응을 하였을 시 2점, 단어를 풀어 설명했거나 유의어로 답변했을 시 1 점, 무응답이나 오반응은 0 점으로 채점하였다. 추론적 질문의 경우에는 구체적이고 정확하게 정반응을 산출한 경우에는 2점, 충 분하진 않지만 오반응이라고 할 수 없는 문항에는 1점, 무응답이나 오반응에는 0 점으로 채점하였다. 각 유형 별 질문의 총점은 질문의 수(10)×점수(2)로 20점으로 구성되었으며 이를 백분율로 변환하 여 분석하였다. 연구자 1 인과 채점 기준을 숙지하였고 2 급 언어재 활사 자격증을 소지한 언어병리학과 석사과정 연구생 1 인이 전체 자료의 $50 \%$ 분량을 분석하여 이야기 이해 과제에 대한 평가자 간 신뢰도를 산출하였다. 참조적 이야기 이해 과제에서는 $100 \%$, 추론 적 이야기 이해 과제에서는 $93.75 \%$ 일치도가 나타났다.

집행기능의 하위 과제의 수행력은 E-prime 2.0 프로그램을 통해 기록된 정확도와 반응시간을 사용하여 분석되었다. 각 문항에서 아동이 정반응 할 시 1 점, 오반응 시 0 점을 부여하였으며 $n$-back, flanker task의 점수는 0 점에서 최대 50 점이었고 DCCS의 점수는 0 점에서 최대 24 점이었다. 이때 모든 과제의 정확도는 원점수를 백 분율로 변환하여 분석하였다. 또한 정확한 인지적 반응을 측정하 기 위해 각 대상자의 반응시간 평균 데이터를 기준으로 -2 SD 미만, $+2 \mathrm{SD}$ 이상의 데이터는 제외하였다(Kail \& Salthouse, 1994).
시선추적기(Eye-tracker)를 통해 측정된 시선 처리 과정은 소프 트웨어 ‘Be Gaze 3.5’를 사용하여 평균 시선고정 시간(average fixation duration)을 분석하였으며 고정의 기준은 그림과 관련한 과제 에 일반적으로 사용하는 $200 \mathrm{~ms}$ 을 기준으로 설정하였다(Holmqvist et al., 2011; Yim et al., 2019). 평균 시선고정 시간은 전체 이 야기 과제 중 $\mathrm{AOI}$ 에 $200 \mathrm{~ms}$ 이상 시선을 고정한 시간인 시선고정 시간(Total time of AOI fixation)을 $200 \mathrm{~ms}$ 이상 AOI를 본 시선고 정 횟수(Total fixation number on AOI)로 나눈 시간을 의미한다 (Yim et al., 2019). 이때 전체 이야기 과제를 응시한 Tracking ratio 가 $75 \%$ 미만인 대상자는 분석에서 제외하였으며(Holmqvist et al., 2011; Yim et al., 2019) 제외된 데이터는 총 4명(SLI 1명, TD 3명)으 로 전체 데이터의 $14.29 \%$ 가 미포함되었다.

\section{통계분석}

본 연구의 모든 통계적 분석은 SPSS ver. 25 (SPSS Inc., Chicago, $\mathrm{IL}, \mathrm{USA}$ )를 사용하였다. 집단 간 참조 및 추론적 이야기 이해력의 차이를 알아보기 위해 각 유형 당 이야기 이해 점수에 따라 이원혼 합분산분석(two-way mixed ANOVA)을 실시하였다. 집행기능의 하위 요소에 따른 집단 간 차이를 알아보기 위하여 집행기능의 하 위 과제인 $n$-back, flanker, DCCS 과제의 정확도를 각각 일원배치 분산분석(one-way ANOVA)으로 분석하였으며 정확한 정확도 측 정을 위해 반응시간이 통제되었는지 확인하기 위하여 각 집행기능 의 하위 과제의 반응시간을 일원배치분산분석(one-way ANOVA) 을 통해 분석하였다. 또한 이야기 처리 과정에 따른 집단 간 차이를 알아보기 위하여 평균 시선고정 시간을 일원배치분산분석(oneway ANOVA)으로 분석하였다. 두 집단 및 집단 별 이야기 이해력, 집행기능, 이야기 처리 과정 간 상관관계를 확인하기 위해 Pearson 적률 상관계수(Pearson correlation coefficient)를 사용하였으며 추론 및 참조적 이야기 이해 능력을 예측하는 집행기능 및 이야기 처리 과정의 하위 요소를 찾기 위해 단계적 중다회귀분석(Stepwise multiple regression)을 실시하였다. 


\section{연구결과}

\section{참조 및 추론적 이야기 이해 과제 수행 결과}

집단 간 참조 및 추론적 이야기 이해 능력의 차이를 알아보기 위 해 이원혼합분산분석(two-way mixed ANOVA)을 실시하였다. 그 결과, 추론적 이해 점수보다참조적 이해 점수가 유의하게 높았으며 $\left(F_{(1,26)}=31.234, p=.000\right)$ 단순언어장애 아동 집단보다 일반 아동 집 단의 수행력이 통계적으로 유의하게 높았다 $\left(F_{(1,26)}=34.459, p=.000\right)$ 이는 아동들이 추론적으로 이야기를 이해하는 것을 더 어려워하 며 단순언어장애 아동이 일반 아동들보다 이야기 이해에 어려움을 보인다는 것을 뜻한다. 하지만 집단에 따른 참조적 이해 점수와 추 론적 이해 점수의 이차 상호작용은 나타나지 않았다 $\left(F_{(1,26)}=0.997\right.$, $p=.327)$. 이에 대한 결과를 Table 2와 Figure 5에 제시하였다.

\section{집행기능 하위 항목 과제 수행 결과}

집행기능의 하위 영역인 갱신 기능, 억제 기능, 전환 기능 과제 수 행력의 집단 간 비교를 위해 일원배치분산분석(one-way ANOVA) 을 실시하였다. 또한 집행기능의 하위 과제의 정확도가 반응시간에 영향을 받았는지 알아보기 위해 일원배치분산분석(one-way $\mathrm{ANOVA}$ )을 통해 각 과제의 집단 간 반응시간 차이를 분석하였다. $n$-back 과제 $\left(F_{(1,27)}=0.008, p=.928\right)$, flanker 과제 $\left(F_{(1,27)}=0.708\right.$,

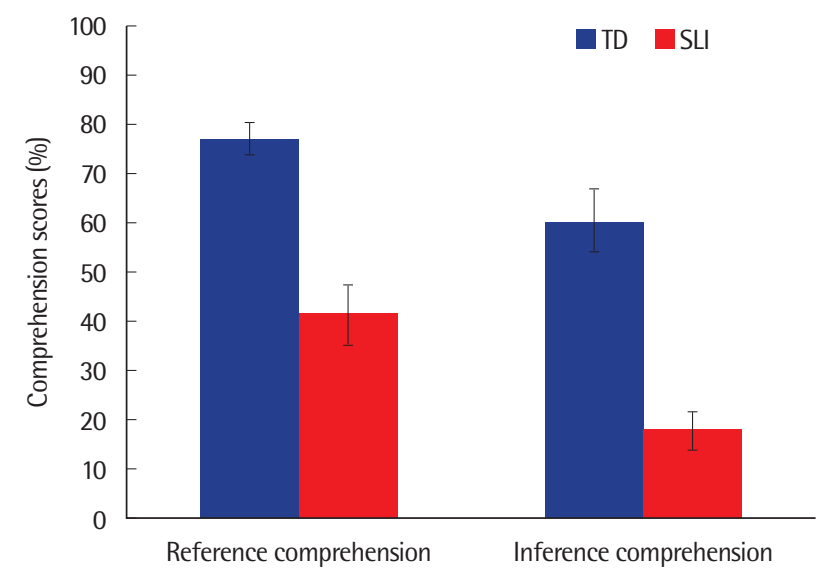

Figure 5. Child's accuracy of story comprehension by two groups. $\mathrm{TD}=$ typically developing children; $S \mathrm{LI}=$ specific language impairment.

Table 2. Performance results on story comprehension

\begin{tabular}{lcc}
\hline & TD (N=17) & SLI (N=11) \\
\hline Reference comprehension scores (\%) & $77.06(13.24)$ & $41.36(20.26)$ \\
Inference comprehension scores (\%) & $60.59(26.86)$ & $17.73(12.52)$ \\
\hline
\end{tabular}

Values are presented as mean (SD).

TD = typically developing children; SLI = specific language impairment. $p=.408), \operatorname{DCCS}$ 과제 $\left(F_{(1,27)}=0.696, p=.412\right)$ 의 반응시간에서 집단 차가 모두 나타나지 않았으므로 집행기능 하위 과제의 정확도 분 석에 대한 통제가 적절히 이루어졌다. 이에 대한 기술통계는 Table 3에 제시되었다.

\section{갱신 과제 $(n-\mathrm{back})$ 수행결과}

갱신 능력을 측정하는 $n$-back 과제에서 단순언어장애 아동 집단 의 과제 수행력은 $54.73(\mathrm{SD}=24.37)$, 일반 아동 집단의 과제 수행 력은 $70.00(\mathrm{SD}=14.93)$ 으로 단순언어장애 아동 집단보다 일반 아 동 집단의 $n$-back 과제 정확도가 유의하게 높았다 $\left(F_{(1,27)}=4.261\right.$, $p=.049)$. 이에 대한 결과는 Table 4에 제시되었다.

\section{억제 과제(flanker) 수행 결과}

억제 능력을 측정하기 위한 flanker 과제에서 단순언어장애 아 동 집단의 과제 수행력은 $78.00(\mathrm{SD}=14.72)$, 일반 아동 집단의 과제 수행력은 $88.12(\mathrm{SD}=11.63)$ 로 단순언어장애 아동에 비해 일반 아 동의 억제 기능이 통계적으로 유의미한 수준에 가깝게 높은 경향 성을 보였다 $\left(F_{(1,27)}=4.103, p=.053\right)$. 이에 대한 결과는 Table 4 에 제 시되었다.

\section{전환 과제(DCCS) 수행 결과}

전환 능력을 측정하기 위한 DCCS 과제에서 단순언어장애 아동 집단의 과제 수행력은 $62.88(\mathrm{SD}=13.88)$, 일반 아동 집단의 과제 수행력은 $75.98(\mathrm{SD}=13.30)$ 로 단순언어장애 아동 집단보다 일반

Table 3. Response time results on executive functions

\begin{tabular}{lccc}
\hline & TD (N=17) & SLI (N=11) & $F$ \\
\hline n-back_RT (ms) & $1537.80(269.96)$ & $1549.36(403.95)$ & 0.008 \\
flanker_RT (ms) & $1683.31(723.69)$ & $1926.34(781.12)$ & 0.708 \\
DCCS_RT (ms) & $2035.26(660.13)$ & $2271.32(832.31)$ & 0.696 \\
\hline
\end{tabular}

Values are presented as mean (SD).

$\mathrm{TD}=$ typically developing children; $\mathrm{SL}$ = specific language impairment; $\mathrm{RT}=$ Response time; DCCS= Dimensional Change Card Sort.

Table 4. Performance results on executive functions

\begin{tabular}{lccl}
\hline & TD (N=17) & SLI (N=11) & \multicolumn{1}{c}{$F$} \\
\hline n-back_Acc (\%) & $70.00(14.93)$ & $54.73(24.37)$ & $4.261^{*}$ \\
flanker_Acc (\%) & $88.12(11.63)$ & $78.00(14.72)$ & 4.103 \\
DCCS_Acc (\%) & $75.98(13.30)$ & $62.88(13.88)$ & $6.267^{*}$ \\
\hline
\end{tabular}

Values are presented as mean (SD).

$\mathrm{TD}=$ typically developing children; $\mathrm{SLI}=$ specific language impairment; $\mathrm{Acc}=\mathrm{Accuracy}$; DCCS = Dimensional Change Card Sort.

${ }^{*} p<.05$. 
아동 집단의 DCCS 과제 정확도가 통계적으로 유의하게 높았다 $\left(F_{(1,27)}=6.267, p=.019\right)$. 이에 대한 결과는 Table 4 에 제시되었다.

\section{시선추적기를 활용한 이야기 이해 처리 과정 수행 결과}

집단 간 평균 시선고정 시간의 차이를 알아보기 위해 일원배치 분산분석(one-way ANOVA)을 실시하였다. 단순언어장애 아동 집 단의 평균 시선고정 시간은 $434.84(\mathrm{SD}=74.32)$ 이고 일반 아동 집 단의 평균 시선고정 시간은 $518.51(\mathrm{SD}=85.08)$ 로 일반 아동의 평 균 시선고정 시간이 단순언어장애 아동의 평균 시선고정 시간보다 유의하게 길게 나타났다 $\left(F_{(1,23)}=6.246, p=.020\right)$. 이에 대한 결과는 Table 5에 제시되었다.

\section{이야기 이해력, 집행기능, 이야기 처리 과정 간 상관관계}

두 집단 및 집단 별 이야기 이해력, 집행기능, 이야기 처리 과정 간 상관관계를 알아보기 위하여 Pearson 적률 상관계수를 사용하였다.

두 집단의 상관관계 분석 결과, 참조적 이야기 이해 점수는 추론 적 이야기 이해 점수 $(r=.797, p=.000), n$-back_Acc $(r=.516, p=$ $.005)$, flanker_Acc $(r=.518, p=.005)$, DCCS_Acc $(r=.515, p=$ $.005)$, 평균 시선고정 시간 $(r=.531, p=.008)$ 과 정적 상관을 보였다. 추론적 이야기 이해 점수는 $n$-back_Acc $(r=.508, p=.006)$, flanker_Acc $(r=.518, p=.005), \mathrm{DCCS} \_\mathrm{Acc}(r=.560, p=.002)$, 평균 시 선고정 시간 $(r=.477, p=.019)$ 과 유의한 정적 상관관계가 나타났다. $n$-back_Acc는 flanker_Acc $(r=.682, p=.000)$, DCCS_Acc $(\mathrm{r}=$ $.468, p=.012)$, 평균 시선고정 시간 $(r=.438, p=.032)$ 과 유의한 정적 상관을 보였으며 flanker_Acc와 DCCS_Acc $(r=.481, p=.010)$ 도

Table 5. Performance results on story processing ability

\begin{tabular}{lccc}
\hline & $\mathrm{TD}(\mathrm{N}=14)$ & $\mathrm{SLI}(\mathrm{N}=10)$ & $F$ \\
\hline Average fixation duration $(\mathrm{ms})$ & $518.51(85.08)$ & $434.84(74.32)$ & $6.246^{*}$ \\
\hline
\end{tabular}

Values are presented as mean (SD).

$\mathrm{TD}=$ typically developing children; $\mathrm{SLI}=$ specific language impairment. ${ }^{*} p<.05$.
정적 상관관계를 보였다. 자세한 결과는 Table 6에 제시하였다.

단순언어장애 아동 집단에서는 $n$-back_Acc와flanker_Acc $(\mathrm{r}=$ $.693, p=.018)$ 간 정적 상관관계만 나타났다.

일반 아동 집단의 변인 간 상관관계를 살펴보면, 참조적 이야기 이해 점수와 추론적 이야기 이해 점수 $(r=.770, p=.000), n$-back_ $\operatorname{Acc}(r=.787, p=.000)$, 평균 시선고정 시간 $(r=.627, p=.016)$ 에서 정적 상관관계가 나타났다. 또한 추론적 이야기 이해 점수와 $n$ back_Acc $(r=.639, p=.006)$, flanker_Acc $(r=.498, p=.042)$, $\mathrm{DCCS} \_\mathrm{Acc}(r=.505, p=.039)$ 간 통계적으로 유의한 정적 상관관 계를 보였다. $n$-back_Acc는 flanker_Acc $(r=.563, p=.019)$, 평균 시선고정 시간 $(r=.586, p=.028)$ 과 정적 상관관계를 보였으며 flanker_Acc와 DCCS_Acc $(r=.551, p=.022)$ 에서도 유의한 정적 상관이 나타났다.

단순언어장애 아동 및 일반 아동 집단의 이야기 이해, 집행기능, 이야기 처리 과정에 관한 상관관계는 Figure 6에 제시하였다.

\section{참조적 이해력 및 추론적 이해력 예측요인}

두 집단 및 집단별 참조적 이해력과 추론적 이해력을 예측하는 요인이 무엇인지 알아보기 위해 단계적 중다회기분석(Stepwise multiple regression)을 실시하였다. 독립변수로는 집행기능 하위 과 제( $n$-back, flanker, DCCS)의 정확도와 이야기 처리 과정(평균 시 선고정 시간) 변인, 총 4 가지를 대입하였다.

두 집단의 참조적 이야기 이해력 분석 결과, 1 단계 분석에서 평균 시선고정 시간이 참조적 이해력을 $28.2 \%$ 예측하였으며 $\left(F_{(1,23)}=8.656\right.$, $\left.\mathrm{R}^{2}=.282, p=.008\right) 2$ 단계 분석에서는 1 단계 분석에 flanker 과제의 정확도가 $19.2 \%$ 설명력을 더해 $47.4 \%$ 로 참조적 이해력을 예측하는 것으로 나타났다 $\left(F_{(2,23)}=9.444, \mathrm{R}^{2}=.474, p=.001\right)$. 또한 두 집단의 추론적 이야기 이해력 분석 결과, 1 단계 분석에서는 flanker 과제의 정확도가 추론적 이해능력을 $28.5 \%$ 설명해주는 것으로 나타났으 며 $\left(F_{(1,23)}=8.750, \mathrm{R}^{2}=.285, p=.007\right) 2$ 단계 분석에서는 1 단계 분석 에 평균 시선고정 시간이 $15.2 \%$ 설명력을 더해 $43.7 \%$ 로 추론적 이

Table 6. The correlation coefficient among tasks

\begin{tabular}{|c|c|c|c|c|c|}
\hline & n-back_Acc & flanker_Acc & DCCS_Acc & $\begin{array}{c}\text { Reference comprehension } \\
\text { scores }\end{array}$ & $\begin{array}{l}\text { Inference comprehension } \\
\text { scores }\end{array}$ \\
\hline flanker_Acc & $.682^{* * *}$ & & & & \\
\hline DCCS_AcC & $.468^{*}$ & $.481^{*}$ & & & \\
\hline Reference comprehension scores & $.516^{* *}$ & $.518^{* *}$ & $.515^{* *}$ & & \\
\hline Inference comprehension scores & $.508^{* *}$ & $.518^{* *}$ & $.560^{* *}$ & $.797^{* * *}$ & \\
\hline Average fixation duration & $.438^{*}$ & 0.172 & 0.223 & $.531^{* *}$ & $.477^{*}$ \\
\hline
\end{tabular}

Acc $=$ Accuracy; DCCS $=$ Dimensional Change Card Sort. ${ }^{*} p<.05,{ }^{* *} p<.01,{ }^{* * *} p<.001$. 

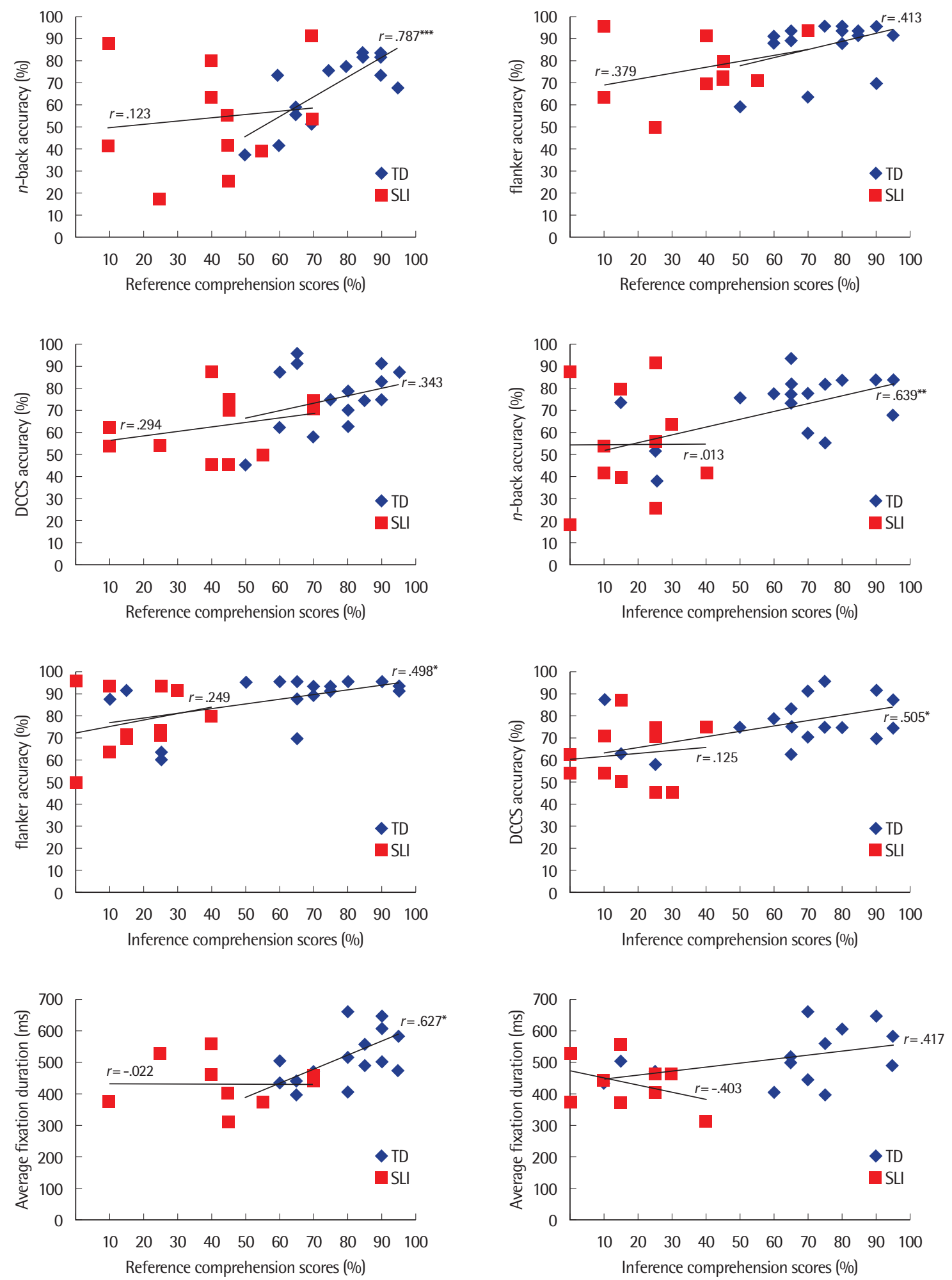

Figure 6. The correlation coefficient among tasks by two groups.

$\mathrm{TD}=$ typically developing children; $\mathrm{SLI}=$ specific language impairment; DCCS = Dimensional Change Card Sort.

${ }^{*} p<.05,{ }^{* *} p<.01,{ }^{* * *} p<.001$. 

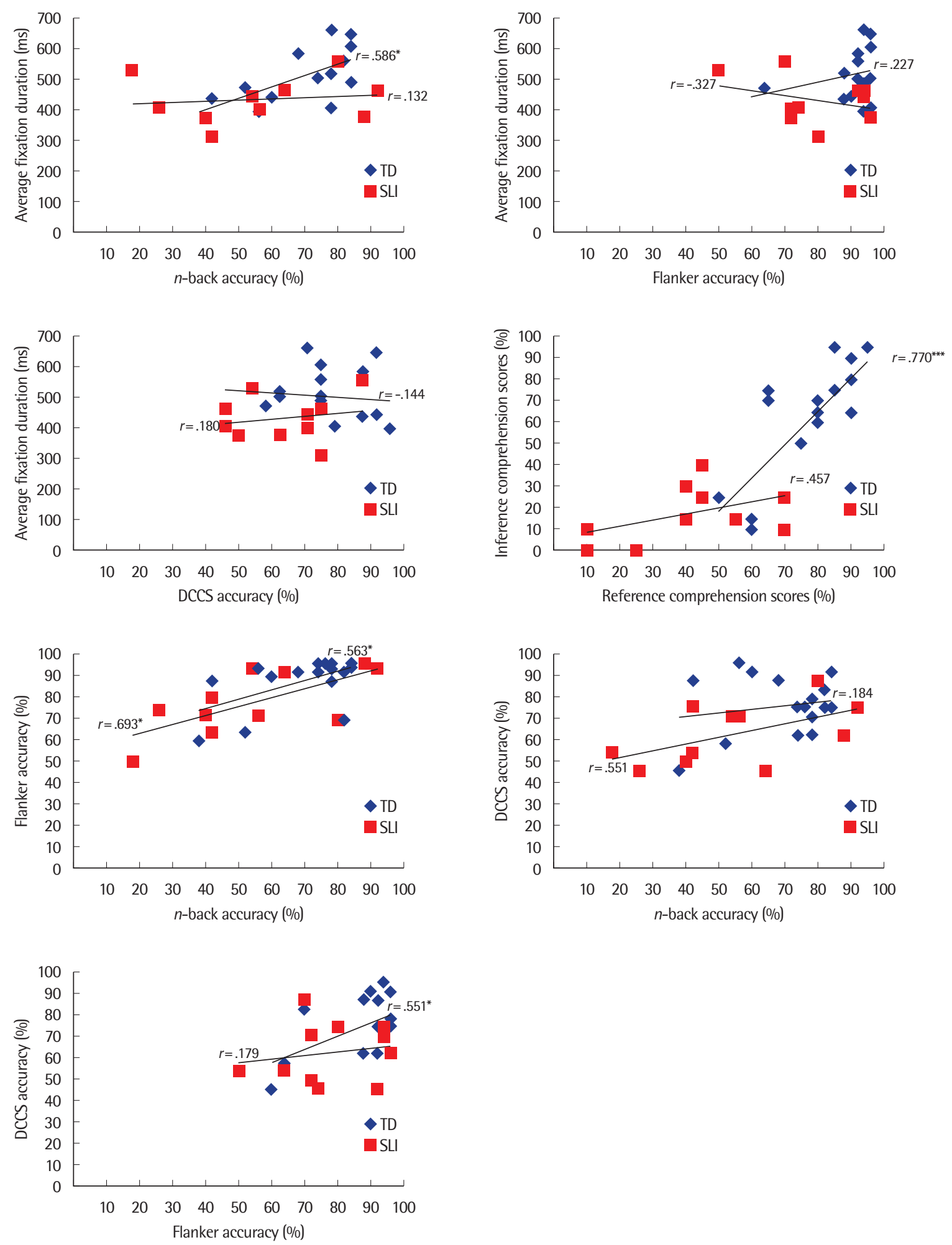

Figure 6. Continued. 
해력을 예측하는 것으로 나타났다 $\left(F_{(2,23)}=8.158, \mathrm{R}^{2}=.437, p=.002\right)$.

단순언어장애 아동 집단에서는 이야기 이해력을 설명해주는 예 측 변인이 나타나지 않았다.

일반 아동 집단의 참조적 이야기 이해력 분석 결과, 1 단계 분석에 서 $n$-back 과제 정확도가참조적 이해력을 $48.6 \%$ 예측하였다 $\left(F_{(1,13)}=\right.$ $\left.11.333, \mathrm{R}^{2}=.486, p=.006\right)$. 추론적 이야기 이해력 분석 결과, $n$-back 과제 정확도가 추론적 이해 능력을 $36.5 \%$ 설명해주었고 $\left(F_{(1,13)}=\right.$ $\left.6.884, \mathrm{R}^{2}=.365, p=.022\right) 2$ 단계 분석에서는 1 단계 분석에 DCCS 과 제 정확도가 $30.7 \%$ 설명력을 더해 $67.2 \%$ 로 추론적 이해력을 예측 하는 것으로 나타났다 $\left(F_{(2,13)}=11.288, \mathrm{R}^{2}=.672, p=.002\right)$.

\section{논의 및 결론}

본 연구에서는 단순언어장애 아동과 일반 아동 간 이야기 이해 력을 참조적 이해력과 추론적 이해력으로 나누어 비교하고 그 과 정에서 일어나는 시선의 움직임을 시선추적기를 이용하여 분석하 였으며 집단 간 집행기능의 차이를 비교하였다. 이에 더해 이야기 이해력, 집행기능, 이야기 처리 과정 변인 간 상관관계를 살펴보고 이야기 이해력을 예측하는 변인을 알아보았다.

연구에 참여한 만 4-6세 학령전기 단순언어장애 아동 집단은 일 반 아동 집단보다 이야기 이해에 결함이 나타났으며 두 집단은 참조 적 이해보다 추론적 이해에서 더 어려움을 보였다. 만 4-6세 학령전 기 어휘발달지연 아동 집단과 일반 아동 집단의 참조 및 추론적 이 해력을 비교한 선행연구와 동일한 결과이다(Lee \& Yim, 2018). 본 연구에서는 참조적 이해의 난이도를 높이기 위하여 이야기 자료에 서 관형절이 포함된 문장의 목적어로 참조적 이해 질문의 답을 설정 하였다. 아동들은 문장의 난이도가 올라갈수록, 서술어 간 간격이 멀어질수록 문장을 이해하는 데 어려움을 보인다(Key-DeLyria \& Altmann, 2016; Park \& Kim, 2009). 단순언어장애 아동이 참조적 으로 이야기를 이해하는 것보다 이야기를 추론하는 것에 일반 아동 보다 어려움을 갖는다는 선행연구(Ford \& Milosky, 2008; Norbury \& Bishop, 2002; Yun \& Kim, 2005)와 달리 담화 내 문장의 복잡성 이 단순언어장애 아동들의 참조적 이야기 이해력에 어려움을 야기 하여 이차상호작용이 나타나지 않았음을 추론해 볼수 있다.

갱신 기능을 알아보기 위해 실시한 $n$-back 과제에서 일반 아동 집단의 수행력이 단순언어장애 아동 집단의 수행력보다 높았다. 단 순언어장애 아동이 일시적으로 들어오는 정보를 기억하고 조작하 는 능력에 어려움을 보일 수 있으며 비구어적 갱신 능력에 일반 아 동보다 낮은 수행력을 보인다는 선행연구와 일치하는 결과이다 (Im-Bolter et al., 2006; Kapa et al., 2017). 또한 음운 및 작업기억의
결함으로 구어적 갱신 능력에서도 단순언어장애 아동이 일반 아동 보다 낮은 수행력을 보였다는 선행연구와 비춰보았을 때(Alt, 2011; Yang \& Yim, 2018), 갱신 기능의 저하가 언어 능력의 어려움과 관련 이 있다고 해석해 볼 수 있다. 불필요한 자극을 억제하고 목표자극 에 반응하는 억제기능을 측정하는 flanker 과제에서는 단순언어장 애 아동 집단이 일반 아동 집단보다 수행력이 낮은 경향을 보였다. 학령전기 단순언어장애 아동은 일반 아동에 비해 간섭을 통제하고 억제하는 데 어려움을 보이며(Roello, Ferretti, Colonnello, \& Levi, 2015; Spaulding, 2010) 의미, 형태, 구문 능력 등의 언어 능력이 높 을수록 억제 기능이 높다고 보고된다(Kaushanskaya, Park, Gangopadhyay, Davidson, \& Weismer, 2017; Khanna \& Boland, 2010). 그러나 일반 아동과 억제 과제에서 유의한 차이를 보이지 않는다 는 선행연구 또한 존재한다(Yang \& Yim, 2018). 목표자극에 반응 하는 조건과 비목표자극에 자신의 반응을 억제하는 정지조건만 있는 선행연구의 과제와 달리 본 연구 과제에서는 방해자극이 포함 되어 선행연구보다 더 복잡한 과제가 제시되었다. 단순언어장애 아 동이 일반 아동보다 억제 능력에서 어려움을 보이는 경향은 과제의 난이도 상승에 따른 인지적 부담에 영향을 받은 것으로 추론된다. 전환 기능을 측정한 DCCS 과제에서도 단순언어장애 아동의 수행 력이 일반 아동의 수행력보다 유의미하게 낮았다. 이러한 결과는 단순언어장애 아동이 일반 아동들보다 현재 집중하고 있는 자극 에서 변화하는 자극에 주의를 전환하고 이전의 자극을 억제하여 규칙이나작업요구에 적응하는 인지 유연성 측면에 더 어려움을 보 였다는 것을 의미하며 학령전기 단순언어장애 아동이 일반 아동보 다 전환 능력에서 어려움을 보인다는 선행연구를 지지한다(Kapa et al., 2017; Roello et al., 2015).

본 연구에서는 비언어적 자극을 통해 단순언어장애 아동과 일반 아동의 집행기능을 전반적으로 살펴보았다. 갱신 기능, 전환 기능 에서 단순언어장애 아동 집단의 수행력이 일반 아동 집단보다 유 의하게 낮았으며 단순언어장애 아동이 일반 아동보다 억제 기능을 어려워하는 경향을 보였다. 이 결과는, 비언어적 정보를 처리하는 기능이 언어 발달과 밀접한 관련이 있으며 단순언어장애 아동들이 언어뿐만 아니라 전반적인 영역에서 어려움을 보인다는 영역-일반 적 결함(domain-general deficit)에 대한 의견을 지지한다(Ebert \& Kohnert, 2011; Kapa et al., 2017; Yang \& Gray, 2017; Yang \& Yim, 2018).

대상자에게 그림으로 시각적인 단서를 제시하고 구어로 이야기 의 내용을 들려주었을 때, 단순언어장애 아동 집단보다 일반 아동 집단이 한 번 $\mathrm{AOI}$ 를 고정할 때 이야기의 내용을 이해하는 데 중심 이 되는 물체나 물건에 더 오랜 시간 동안 시선을 응시하였다. 일반 
아동이 단순언어장애 아동에 비해 관심영역에 더 긴 시선고정 시 간을 가진다는 선행연구를 뒷받침하는 결과이다(Ellis et al., 2015; McMurray et al., 2010; Yoon \& Yim, 2019). 인간은 담화를 듣고 있 는 상황에서 관련 단어를 들은 후 빠르게 시선을 움직여 관련 물체 에 시선을 고정시키며 청각적 자극에 따라 시선의 고정이 변화된다 (Eberhard, Spivey-Knowlton, Sedivy, \& Tanenhaus, 1995; Takacs $\&$ Bus, 2018). 또한 이야기 내에서 의미적 정보를 담고 있는 청각적 자극을 제시하였을 때 해당 영역의 시선고정 시간이 증가한다(Evans \& Saint-Aubin, 2005; Tackas \& Bus, 2018; Yoon \& Yim, 2019). 이야기 과제에서 AOI에 해당하는 영역은 구어 자극을 통해 명시적 으로 제시되었고 이는 이야기를 이해하는 데 필요한 중심 소재였 다. 중심 내용과 관련한 관심영역을 알아차리고 더 높은 집중력과 관심을 보인 일반 아동과 비교하여 단순언어장애 아동은 이야기 이해에 중요한 시각적 단서를 상대적으로 구분하여 집중하기 어려 웠을 것이라고 해석해 볼 수 있다. 그러나 학령전기 어휘발달지연 아동이 일반 아동에 비해 그림책을 볼 때 관심영역에 유의하게 짧 은 평균 시선고정 시간을 보였던 선행연구와는 다른 양상을 보였다 (Yim et al., 2019). 이는 아동에게 제시한 한 장면에 대한 자극의 양 에 기인한 것이라 해석된다. 선행연구에서는 한 장면에 한 가지 이 상의 $\mathrm{AOI}$ 와 다수의 문장이 포함되어 대상자에게 제공된 많은 중요 한 시청각적 자극이 인지 처리 과정에 부담을 주었으며 어휘발달지 연 아동의 제한된 처리 용량이 처리 속도를 저하시켜 정보 처리에 긴 시간이 필요하다고 보고하였다(Yim et al., 2019). 그러나 본 연구 의 경우 $\mathrm{AOI}$ 가 포함된 장면에는 한 개의 $\mathrm{AOI}$ 와 한 개의 관형절이 포함되었으며 이야기의 흐름이 원활하게 이어지도록 최소한으로 추가한 문장을 포함하여 최대 두 문장이 청각적 자극으로 노출되 었다. 장면을 제시하는 시간이 짧았기 때문에 처리 용량과 시간의 측면보다는 청각적 자극 안에서 중요한 시청각적 정보를 찾는 능력 이 단순언어장애 아동에 비해 일반 아동이 긴 시간 동안 $\mathrm{AOI}$ 를 주 시하는 데 영향을 주었을 것이라 해석된다.

전체 대상자의 변인 간 상관관계를 살펴보면 참조적 이해력이 높 을수록 갱신 능력(n-back), 억제 능력(flanker), 전환 능력(DCCS) 과제의 수행력이 높았으며 참조적 이해보다 고차원적 사고를 요구 하는 추론적 질문에서도 집행기능의 하위 세 가지 과제 모두 상관 관계가 나타났다. 이야기 과제에서 일방적으로 정보가 전달되었고 이야기가 모두 끝난 후 아동에게 이야기에 대해 질문하였던 것을 고려할 때, 정보를 기억하고 처리하는 갱신 능력이 이야기가 끝날 때까지 정보를 기억하고 유지하는 데 도움을 주었을 가능성이 시 사되며 이야기 이해력과 갱신 기능의 연관성을 밝힌 선행연구를 지 지한다(Kim et al., 2018; Whitely \& Colozzo, 2013). 또한 계속해서
새로운 에피소드가 이어지는 이야기 과제에서 중요하지 않은 정보 를 억제한 후 의미 있는 정보로 주의를 전환하는 능력이 학령전기 아동들이 정보를 기억하는 데 영향을 주었을 것이라고 해석할 수 있다.

그림책에서는 어휘, 문장 등의 언어 자극뿐만 아니라 다양한 상 황이 담긴 그림 자극 등이 연속적으로 제시되며 이야기 이해를 위 해서는 제시되는 자극에 본인이 원래 가지고 있는 지식, 경험 등을 결합해야 한다(Daneman \& Carpenter, 1980). 어떠한 자극을 동시 에 처리하고 저장해야 할 때 개인이 처리할 수 있는 총 용량을 초과 하면 정보의 손실을 야기한다는 용량제한모델(Capacity limitation model)에 본 연구결과를 대입해보면(Daneman \& Carpenter, 1983), 갱신 능력이 정보의 저장, 즉 단기 기억을 설명하는 기능이므 로 이야기에서 동시에 제시되는 시각 및 청각적 자극을 처리할 때 더 많은 정보를 저장하여 정보의 손실을 최소화할수록 이야기 이 해에 도움이 된다고 해석할 수 있다. 또한 처리 용량의 한계로 집중 해야 할 정보를 선택하고 관리하는 역할인 억제 및 전환 능력이 이 야기 이해의 효율성을 높였을 가능성이 시사된다. 본 연구는, 이야 기 이해와 갱신 능력의 관련성에 더해 이야기 이해와 억제 및 전환 능력과 연관성을 밝힌 것에 시사점을 가진다.

단순언어장애 아동 집단과 일반 아동 집단을 나누어 집단 별 이 야기 이해력과 집행기능의 연관성을 살펴보았을 때, 단순언어장애 아동이 이야기 이해 능력과 집행과제의 수행력 간 상관을 보이지 않았던 결과와 대조하여 일반 아동은 이야기 이해 능력과 집행기 능의 하위 과제 수행력에서 고른 상관관계를 보였다. 집행기능을 적절히 발휘하여 이야기를 이해하는 데 도움을 받았던 일반 아동 과 달리 단순언어장애 아동은 이야기의 특성상 계속해서 입력되는 언어 자극에 집행기능이라는 인지 과정을 효율적으로 사용하지 못 했을 것으로 예상된다. 일반 아동 집단과 대조적으로 어휘발달지 연 아동 집단이 언어 능력과 집행기능의 연관성을 보이지 않았던 선행연구 결과를 지지하며(Yoo \& Yim, 2018) 일반 아동 집단은 갱 신, 억제, 전환 능력에서 어휘력과 상관관계를 보였지만 어휘발달지 연 아동 집단은 억제 능력에서만 어휘력과 상관을 보였던 선행연구 와 일부 맥락을 같이한다(Yang \& Yim, 2018).

또한 전체 집단의 두 가지 이야기 이해 유형과 평균 시선고정 시 간에 유의한 상관관계가 나타났다. 이는 이야기 안에서 관련 명사 구를 말할 때 아동의 시선고정 시간이 증가하며(Luke \& Asplund, 2018) 이야기가 복잡해질수록 시각적 정보에 의존하여 이야기를 이해하는 데 도움을 받아 이해력을 향상시킨다는 의견을 지지한다 (Tackas \& Bus, 2018). 즉, 시각 및 언어 정보는 작업기억에서 동시에 처리되며 의미적 단서에 시각적 정보를 정확하고 집중적으로 결합 
할수록 담화를 이해하는 데 도움을 받을 수 있다고 해석할 수 있다.

집단 별 비교에서는 단순언어장애 아동 집단이 참조적 이야기 이해력과 평균 시선고정 시간에 연관성이 드러나지 않은 것과 대조 하여 일반 아동 집단은 이야기에서 참조적 정보를 파악하는 데 그 림책 내의 핵심적 시각적 정보에 도움을 받았다고 추론해 볼 수 있 다. Yim 등(2019)은 학령전기의 일반 아동에게서 이야기 이해력이 높을수록 첫 시선고정 지속시간이 길었다고 밝혔는데, 본 연구와 의 연관성을 살펴보면 일반 아동의 이야기 이해력은 시선고정 시간 변수의 지속시간과 정적 관련성을 가지며 단순언어장애 아동의 경 우에 그림책을 볼 때 시각과 청각의 정보를 통합하여 이야기를 이 해하는 것에 어려움이 있다는 것을 예상해 볼 수 있다.

모든 대상자의 평균 시선고정 시간과 $n$-back 과제 간 정적 상관 관계는 이야기에서 중요한 의미가 담긴 시각적 정보에 아동들이 한 번 시선을 고정할 때 그 정보를 오랫동안 응시할수록 단기적인 정 보를 저장하는 과제의 수행력이 높았다고 해석할 수 있다. 갱신 기 능의 발달 이전에는 '선택적 주의집중의 유지 능력'이 선행되어야 하며(Garon et al., 2008) 안구 운동에는 개인의 관심이 반영된다 (Just \& Carpenter, 1980). 즉, 받아들여야 하는 중요한 정보에 주의 를 둔다는 공통점에서 두 영역의 연관성이 나타났을 가능성이 시 사된다.

그러나 갱신 과제와 평균 시선고정 시간에서도 일반 아동이 정 적 상관관계를 보인 것에 비해 단순언어장애 아동 집단에서는 두 변인의 관련성을 찾을 수 없었다. 본 연구에서는 시각적 자극을 바 탕으로 갱신 과제를 제공하여 정보를 저장하고 조작하는 능력을 평가하였으며 일반적으로 시선고정 시간은 시각을 통해 정보 처리 가 일어나고 있다는 것을 의미한다(Rayner, 1978). 각 변인이 주의 력뿐만 아니라 시각적 정보 처리라는 공통적 기제를 공유해야 하 지만, 단순언어장애 아동이 일반 아동에 비해 두 영역이 모두 요구 하는 시각적 주의 지속력에 결함을 보이는 것을 고려할 때 충분히 예상 가능한 결과이다(Finneran, Francis, \& Leonard, 2009). 본 결 과는 이야기 이해에 필요한 오프라인(off-line) 과제와 온라인(online) 과제의 연관성을 밝힌 것에 의의를 둔다.

각 과제 내 상관관계를 살펴보면, 전체 대상자와 일반 아동 집단 에서 참조적 이야기 이해 능력과 추론적 이야기 이해 능력 간 유의 한 정적 상관을 보였다. 명시적으로 드러난 내용을 파악하는 것이 추론을 위한 재료가 되어 이야기가 내포한 메시지를 파악하는 데 도움을 주었다고 해석된다. 그러나 단순언어장애 아동의 경우 참조 적 이해력과 추론적 이해력 간 상관관계를 보이지 않았으며 이들 이 단순히 추론에 필요한 언어 능력, 배경 지식, 개인의 경험 등 (Daneman \& Carpenter, 1980)의 결핍으로 추론적 이야기 이해 능
력에 부족함을 보이기도 하지만 참조적 정보를 이용하여 추론적 정보를 도출하는 과정상에 어려움을 가질 수 있음이 시사된다.

두 집단에서는 집행기능의 모든 하위 과제 간 상관을 보였고 일 반 아동 집단에서는 갱신 과제와 억제 과제, 억제 과제와 전환 과제 의 수행력 간 정적 상관을 보였으며 단순언어장애 아동은 갱신 과 제와 억제 과제에서만 상관관계가 나타났다. 집행기능의 하위 요소 들은 각 요소들을 조정하는 가장 상위 기능인 전환 기능까지 유기 적으로 연결되어 작용되는데(Garon et al., 2008; Miyake et al., 2000) 일반 아동 집단에 비해 단순언어장애 아동들이 집행기능의 각 요소간 약한 결합을 보이고 있음을 알 수 있으며 이러한 차이가 단순언어장애 아동의 영역-일반적 결함에 대한 의견에 다시 한 번 힘을 실어준다(Ebert \& Kohnert, 2011; Kapa et al., 2017; Yang \& Gray, 2017; Yang \& Yim, 2018).

두 집단의 참조적 이해력과 추론적 이해력을 예측하는 변인은 억제 과제인 flanker 수행력, 평균 시선고정 시간이었다. 본인의 기 존 지식 및 이야기 내에서 불필요한 부분의 간섭을 피해 핵심적인 정보를 고르고 저장하여 인지적 처리 부담을 낮추는 과정이 참조 및 추론적 이해력을 설명했을 것이라고 해석된다. 또한 평균 시선 고정 시간이 공통적으로 참조적 이해력 및 추론적 이해에 대한 설 명력을 지녔으며 중심 소재에 집중적으로 오래 응시하여 내용을 받아들일 충분한 처리 시간을 갖는 것이 아동들의 이야기 이해력 에 영향을 줄 수 있다는 가능성을 제시한다. 이야기는 단어, 문장 등의 조합으로 이루어져 있지만 학령전기 아동들의 이야기 이해력 은 언어 능력에만 국한된 것이 아니라 집행기능과 같은 인지 처리 과정과 시각적 자극 등 여러 가지 요인의 결합으로 이루어진다고 해 석된다.

집단 별로 세분화하여 이야기 이해를 설명하는 변인을 알아보았 을 때, 단순언어장애 아동 집단에서 이야기 이해력 예측 요인이 나 타나지 않은 것과 달리 일반 아동의 참조적 이야기 이해 능력을 설 명하는 변인은 갱신 기능을 나타내는 $n$-back 과제 수행력이었으며 추론적 이야기 이해 능력을 설명하는 변인은 갱신 과제인 $n$-back 수행력, 전환과제인 DCCS 수행력이었다. 갱신 과제 수행력은 참조 적 이해력뿐만 아니라 추론적 이해력을 가장 강력하게 예측하는 변인으로 설명된다. 참조적 이해력은 추론적 이해력을 위한 필수 조건이며 이야기의 전체 내용을 이해하지 않더라도 한 장면에서 명 시적으로 드러나는 시각이나 청각 단서만 기억하고도 충분히 답할 수 있다. 이러한 관점에서 정보를 받아들이고 저장하는 갱신 능력 이 일반 아동의 이야기 이해의 결정적인 역할을 한다고 볼 수 있다. 이는 갱신 기능이 이야기 이해 같은 복잡한 언어 과정에서 정보를 저장하고 처리하며 제한된 용량의 저장 공간을 최대로 활용하는 
것이 이야기 이해에 핵심적인 역할을 한다고 주장한 선행연구들을 지지하는 결과이다(Daneman \& Carpenter, 1980; Just \& Carpenter, 1992; Yun \& Kim, 2005).

Garon 등(2008)에 의하면 작업기억 능력이라고 불리는 갱신 기 능, 억제 기능, 전환 기능 순으로 위계적 발달이 이루어지며 위로 올 라갈수록 고차원의 인지 능력을 요구한다고 설명하였다. 추론적 이야기 이해를 위해서는 장면마다 주는 메시지를 통합하여 이해하 는 과정이 필요하기 때문에 이해에 필요한 부분은 저장하고 불필요 한 정보는 억제한 후 다른 중요한 정보로 주의를 옮기는 능력인 전 환 능력이 일반 아동의 추론적 이야기 이해 능력을 가장 크게 설명 했을 것이라고 예측해 볼 수 있다. 즉, 갱신 기능보다 전환 기능이 집 행기능에서 상위 개념이라는 것을 고려했을 때 더 높은 수준의 인 지적 처리를 요하는 추론적 이해력이 참조적 이해력보다상위 집행 기능에 영향을 받았다고 예상된다. 또한 만 4-5세 일반 아동이 이 미 일어난 일을 추론하기 위해서는 집행기능의 하위 요소 중 전환 기능이 가장 중요하다고 주장한 선행연구를 뒷받침한다(Yoon \& Park, 2014).

본 연구는 오프라인 방식인 집행기능 과제와 온라인 방식인 시선 추적기를 이용하여 학령전기 일반 아동 및 단순언어장애 아동의 이야기 이해력 결함이 어떤 영역과 관련이 있는지 다각도로 분석 해 보았다는 점에서 학문적 의의를 둔다. 따라서 임상현장에서는 중요한 의미를 담고 있는 영역에 집중적으로 단순언어장애 아동의 시선이 머무를 수 있게 하여 학습이 이루어지는 것을 돕고 집행기 능의 역할을 촉진하여 이야기를 효율적으로 파악할 수 있도록 자 극하는 방안이 고려되어야 한다. 그러나 집행기능 과제의 변수는 백분율로, 시선추적 과제의 변수는 시간 단위로 분석되어 변수의 단위가 일치하지 않았던 것에 한계점을 갖는다. 후속연구에서는 집 행기능을 반응시간 등의 시간 변수로 측정하여 시선 추적 변수와 연관성을 살펴본다면 보다 풍부한 논의가 이루어질 것이다. 마지막 으로 후속연구에서는 다양한 시선추적 변수를 활용하여 아동의 안구 운동을 보다 면밀히 관찰하고 의미적 정보를 가진 청각적 자 극에 따라 시선에 영향을 준다는 선행연구(Evans \& Saint-Aubin, 2005)에 따라 한 장면에 여러 가지 $\mathrm{AOI}$ 를 설정하여 시선의 패턴을 심도 있게 분석하는 과정이 필요할 것이다.

\section{REFERENCES}

Aljahlan, Y., \& Spaulding, T. J. (2019). The impact of manipulating attentional shifting demands on preschool children with specific language impairment. Journal of Speech, Language, and Hearing Research, 62(2), 324-336.
Alt, M. (2011). Phonological working memory impairments in children with specific language impairment: where does the problem lie?. Journal of Communication Disorders, 44(2), 173-185.

Archibald, L. M., \& Gathercole, S. E. (2006). Short-term and working memory in specific language impairment. International Journal of Language \& Communication Disorders, 41(6), 675-693.

Bishop, D. V. M., \& Adams, C. (1990). A prospective study of the relationship between specific language impairment, phonological disorders and reading retardation. Journal of Child Psychology and Psychiatry, 31(7), 10271050.

Botting, N., \& Adams, C. (2005). Semantic and inferencing abilities in children with communication disorders. International Journal of Language \& Communication Disorders, 40(1), 49-66.

Brocki, K. C., \& Bohlin, G. (2004). Executive functions in children aged 6 to 13: a dimensional and developmental study. Developmental Neuropsychology, 26(2), 571-593.

Brookshire, J., Scharff, L. F., \& Moses, L. E. (2002). The influence of illustrations on children's book preferences and comprehension. Reading Psychology, 23(4), 323-339.

Brookshire, R. H. (2014). Introduction to neurogenic communication disorders (7th ed.., M. Kwon, Trans.). Seoul: Pakhaksa.

Bus, A. G., Takacs, Z. K., \& Kegel, C. A. (2015). Affordances and limitations of electronic storybooks for young children's emergent literacy. Developmental Review, 35, 79-97.

Chun, S., \& Yim, D. (2017). A comparative study of chunking mechanism in children with and without language delay. Communication Sciences \& Disorders, 22(2), 233-244.

Daneman, M., \& Carpenter, P. A. (1980). Individual differences in working memory and reading. Journal of Verbal Learning and Verbal Behavior, 19(4), 450-466.

Daneman, M., \& Carpenter, P. A. (1983). Individual differences in integrating information between and within sentences. Journal of Experimental Psychology: Learning, Memory, and Cognition, 9(4), 561-584.

del Angel, J., Cortez, J., Juarez, D., Guerrero, M., García, A., Ramírez, C., \& Valdez, P. (2015). Effects of sleep reduction on the phonological and visuospatial components of working memory. Sleep Science, 8(2), 68-74.

Desmarais, C., Nadeau, L., Trudeau, N., Filiatrault-Veilleux, P., \& MaxèsFournier, C. (2013). Intervention for improving comprehension in 4-6 year old children with specific language impairment: practicing inferencing is a good thing. Clinical Linguistics \& Phonetics, 27(6-7), 540-552. 
Diamond, A. (2013). Executive functions. Annual Review of Psychology, 64, 135-168.

Diamond, A., Barnett, W. S., Thomas, J., \& Munro, S. (2007). Preschool program improves cognitive control. Science, 318(5855), 1387-1388.

Eberhard, K. M., Spivey-Knowlton, M. J., Sedivy, J. C., \& Tanenhaus, M. K. (1995). Eye movements as a window into real-time spoken language comprehension in natural contexts. Journal of Psycholinguistic Research, 24(6), 409-436.

Ebert, K. D., \& Kohnert, K. (2011). Sustained attention in children with primary language impairment: a meta-analysis. Journal of Speech, Language, and Hearing Research, 54(5), 1372-1384.

Ebert, K. D., Rak, D., Slawny, C. M., \& Fogg, L. (2019). Attention in bilingual children with developmental language disorder. Journal of Speech, Language, and Hearing Research, 62(4), 979-992.

Ellis Weismer, S., Kaushanskaya, M., Larson, C., Mathée, J., \& Bolt, D. (2018). Executive function skills in school-age children with autism spectrum disorder: association with language abilities. Journal of Speech, Language, and Hearing Research, 61(11), 2641-2658.

Ellis, E. M., Borovsky, A., Elman, J. L., \& Evans, J. L. (2015). Novel word learning: An eye-tracking study. Are 18-month-old late talkers really different from their typical peers?. Journal of Communication Disorders, 58, 143-157.

Evans, J. L. (2002). Variability incomprehension strategy use in children with SLI: a dynamical systems account. International Journal of Language and Communication Disorders, 37(2), 95-116.

Evans, J. L., Gillam, R. B., \& Montgomery, J. W. (2018). Cognitive predictors of spoken word recognition in children with and without developmental language disorders. Journal of Speech, Language, and Hearing Research, 61(6), 1409-1425.

Evans, M. A., \& Saint-Aubin, J. (2005). What children are looking at during shared storybook reading: evidence from eye movement monitoring. Psychological Science, 16(11), 913-920.

Fernald, A., \& Marchman, V. A. (2012). Individual differences in lexical processing at 18 months predict vocabulary growth in typically-developing and late-talking toddlers. Child Development, 83(1), 203-222.

Filiatrault-Veilleux, P., Bouchard, C., Trudeau, N., \& Desmarais, C. (2016). Comprehension of inferences in a narrative in 3-to 6-year-old children. Journal of Speech, Language, and Hearing Research, 59(5), 1099-1110.

Finneran, D.A., Francis, A.L., \& Leonard, L.B. (2009). Sustained attention in children with specific language impairment (SLI). Journal of Speech, Lan- guage, and Hearing Research, 52(4), 915-929.

Ford, J. A., \& Milosky, L. M. (2008). Inference generation during discourse and its relation to social competence: an online investigation of abilities of children with and without language impairment. Journal of Speech, Language, and Hearing Research, 51(2), 367-380.

Garon, N., Bryson, S. E., \& Smith, I. M. (2008). Executive function in preschoolers: a review using an integrative framework. Psychological Bulletin, 134(1), 31-60.

Han, J., \& Yim, D. (2018). Korean brief parent report measures of language development in children with vocabulary delay. Journal of Speech-Language \& Hearing Disorders, 27(2), 69-84.

Holmqvist, K., Nyström, M., Andersson, R., Dewhurst, R., Jarodzka,H., \& Van de Weijer, J. (2011). Eye tracking: a comprehensive guide to methods and measures. Oxford: Oxford University Press.

Hutzler, F., \& Wimmer, H. (2004). Eye movements of dyslexic children when reading in a regular orthography. Brain and language, 89(1), 235-242.

Im-Bolter, N., Johnson, J., \& Pascual-Leone, J. (2006). Processing limitations in children with specific language impairment: the role of executive function. Child Development, 77(6), 1822-1841.

Just, M. A., \& Carpenter, P. A. (1980). A theory of reading: from eye fixations to comprehension. Psychological review, 87(4), 329-354.

Just, M. A., \& Carpenter, P. A. (1992). A capacity theory of comprehension: individual differences in working memory. Psychological Review, 99, 122 149.

Kail, R., \& Salthouse, T. A. (1994). Processing speed as a mental capacity. Acta Psychologica, 86(2), 199-225.

Kapa, L. L., Plante, E., \& Doubleday, K. (2017). Applying an integrative framework of executive function to preschoolers with specific language impairment. Journal of Speech, Language, and Hearing Research, 60(8), 2170-2184.

Kaushanskaya, M., Park, J. S., Gangopadhyay, I., Davidson, M. M., \& Weismer, S. E. (2017). The relationship between executive functions and language abilities in children: a latent variables approach. Journal of Speech, Language, and Hearing Research, 60(4), 912-923.

Key-DeLyria, S. E., \& Altmann, L. J. (2016). Executive function and ambiguous sentence comprehension. American Journal of Speech-Language Pathology, 25(2), 252-267.

Khan, K. S., Gugiu, M. R., Justice, L. M., Bowles, R. P., Skibbe, L. E., \& Piasta, S. B. (2016). Age-related progressions in story structure in young children's narratives. Journal of Speech, Language, and Hearing Research, 59(6), 1395- 
1408.

Khanna, M. M., \& Boland, J. E. (2010). Children's use of language context in lexical ambiguity resolution. The Quarterly Journal of Experimental Psychology, 63(1), 160-193.

Kim, J., Sung, J., \& Kim, Y. (2018). The relationship between the working memory abilities and discourse abilities of 5-and 6-year-old children. Journal of Speech-Language \& Hearing Disorders, 27(1), 29-43.

Kim, Y., Hong, G., Kim, K., Jang, H., \& Lee, Y. (2009). Receptive \& expressive vocabulary test (REVT). Seoul: Seoul Community Rehabilitation Center.

Kim, Y., Sung, T., \& Lee, Y. (2003). Preschool receptive-expressive language scale (PRES). Seoul: Seoul Community Rehabilitation Center.

Ladányi, E., \& Lukács, Á. (2019). Word retrieval difficulties and cognitive control in specific language impairment. Journal of Speech, Language, and Hearing Research, 62(4), 918-931.

Lai, M. L., Tsai, M. J., Yang, F. Y., Hsu, C. Y., Liu, T. C., Lee, S. W. Y., ... \& Tsai, C. C. (2013). A review of using eye-tracking technology in exploring learning from 2000 to 2012. Educational Research Review, 10, 90-115.

Lee, S., \& Yim, D. (2018). Caregivers' question use and the contributions of children with vocabulary delay and typically developing children during shared book-reading. Communication Sciences \& Disorders, 23(3), 584596.

Leonard, L. (1998). Children with specific language impairment. Cambridge: MIT Press.

Lezak, M. D., Howieson, D. B., \& Loring, D. W. (2004). Neuropsychological Assessment (4th ed.). New York: Oxford University Press.

Luke, S. G., \& Asplund, A. (2018). Prereaders' eye movements during shared storybook reading are language-mediated but not predictive. Visual Cognition, 26(5), 351-365.

Lund, N. J., \& Duchan, J. F. (1993). Assessing children's language in naturalistic contexts (3rd). New Jersey: Prentie Hall.

McMurray, B., Samelson, V. M., Lee, S. H., \& Tomblin, J. B. (2010). Eyemovements reveal the time-course of online spoken word recognition language impaired and normal adolescents. Cognitive Psychology, 60(1), 1-39.

Miyake, A., Friedman, N. P., Emerson, M. J., Witzki, A. H., Howerter, A., \& Wager, T. D. (2000). The unity and diversity of executive functions and their contributions to complex "frontal lobe" tasks: a latent variable analysis. Cognitive Psychology, 41(1), 49-100.

Moon, S. B., \& Byun, C. J. (2003). Korean Kaufman assessment battery for children (K-ABC). Seoul: Hakjisa.
Norbury, C. F., \& Bishop, D. V. (2002). Inferential processing and story recall in children with communication problems: a comparison of specific language impairment, pragmatic language impairment and high-functioning autism. International Journal of Language \& Communication Disorders, $37(3), 227-251$.

Paivio, A. (2008). The dual coding theory. In S. B. Neuman (Ed.), Educating the other America (pp. 227-242). Baltimore, MD: Paul H. Brookes.

Park, J., \& Kim, Y. (2009). Relative clause sentence comprehension in children with mild intellectual disabilities: cues of additional position and parallel function. Communication Sciences \& Disorders, 14(4), 456-69.

Rayner, K. (1978). Eye movements in reading and information processing. Psychological Bulletin, 85(3), 618-660.

Robertson, D. A., Gernsbacher, M. A., Guidotti, S. J., Robertson, R. R., Irwin, W., Mock, B. J., ... \& Campana, M. E. (2000). Functional neuroanatomy of the cognitive process of mapping during discourse comprehension. Psychological Science, 11(3), 255-260.

Roebuck, H., Sindberg, H., \& Weismer, S. E. (2018). The role of language in nonlinguistic stimuli: comparing inhibition in children with language impairment. Journal of Speech, Language, and Hearing Research, 61(5), 12161225.

Roello, M., Ferretti, M. L., Colonnello, V., \& Levi, G. (2015). When words lead to solutions: executive function deficits in preschool children with specific language impairment. Research in Developmental Disabilities, 37, 216-222.

Sandgren, O., Andersson, R., van de Weijer, J., Hansson, K., \& Sahlén, B. (2014). Coordination of gaze and speech in communication between children with hearing impairment and normal-hearing peers. Journal of Speech, Language, and Hearing Research, 57(3), 942-951.

Spaulding, T. J. (2010). Investigating mechanisms of suppression in preschool children with specific language impairment. Journal of Speech, Language, and Hearing Research, 53(15), 725-738.

Takacs, Z. K., \& Bus, A. G. (2018). How pictures in picture storybooks support young children's story comprehension: an eye-tracking experiment. Journal of Experimental Child Psychology, 174, 1-12.

van Kleeck, A. (2008). Providing preschool foundations for later reading comprehension: the importance of and ideas for targeting inferencing in storybook-sharing interventions. Psychology in the Schools, 45(7), 627-643.

Vugs, B., Hendriks, M., Cuperus, J., Knoors, H., \& Verhoeven, L. (2017). Developmental associations between working memory and language in children with specific language impairment: a longitudinal study. Journal of 
Speech, Language, and Hearing Research, 60(11), 3284-3294.

Wada, J. A., Clarke, R., \& Hamm, A. (1975). Cerebral hemispheric asymmetry in humans: cortical speech zones in 100 adult and 100 infant brains. Archives of Neurology, 32(4), 239-246.

Whitely, C., \& Colozzo, P. (2013). Who's who? Memory updating and character reference in children's narratives. Journal of Speech, Language, and Hearing Research, 56(5), 1625-1636.

Yang, H. C., \& Gray, S. (2017). Executive function in preschoolers with primary language impairment. Journal of Speech, Language, and Hearing Research, 60(2), 379-392.

Yang, Y., \& Yim, D. (2018). The role of executive function for vocabulary acquisition and word learning in preschool-age children with and without vocabulary delay. Communication Sciences \& Disorders, 23(1), 43-59.

Yim, D., Park, W., Kim, S., Han, J., Song, E., \& Son, J. (2019). An eye-tracking study of picture book reading in preschool children with and without language delay. Communication Sciences \& Disorders, 24(2), 299-316.
Yoo, J., \& Yim, D. (2018). Relationship among executive functions, vocabulary and reading skills in school-aged children with and without poor vocabulary. Communication Sciences \& Disorders, 23(3), 570-583.

Yoon, J., \& Park, Y. (2014). Preschool children's reasoning about the temporal order of past and future events and executive function. The Korean Psychological Association, 27(4), 51-74.

Yoon, S., \& Yim, D. (2019). Sustained attention of children with and without specific language impairment and the relations with quick incidental learning using eye-tracker. Communication Sciences \& Disorders, 24(4), 852-867.

Yun, H., \& Kim, Y. (2005). Story comprehension abilities in school-age children with specific language impairment. Communication Sciences \& Disorders, 10(3), 1-56.

Zelazo, P. D. (2006). The dimensional change card sort (DCCS): a method of assessing executive function in children. Nature Protocols, 1(1), 297-301. 
Appendix 1. Script of the picture book Charlie's Story

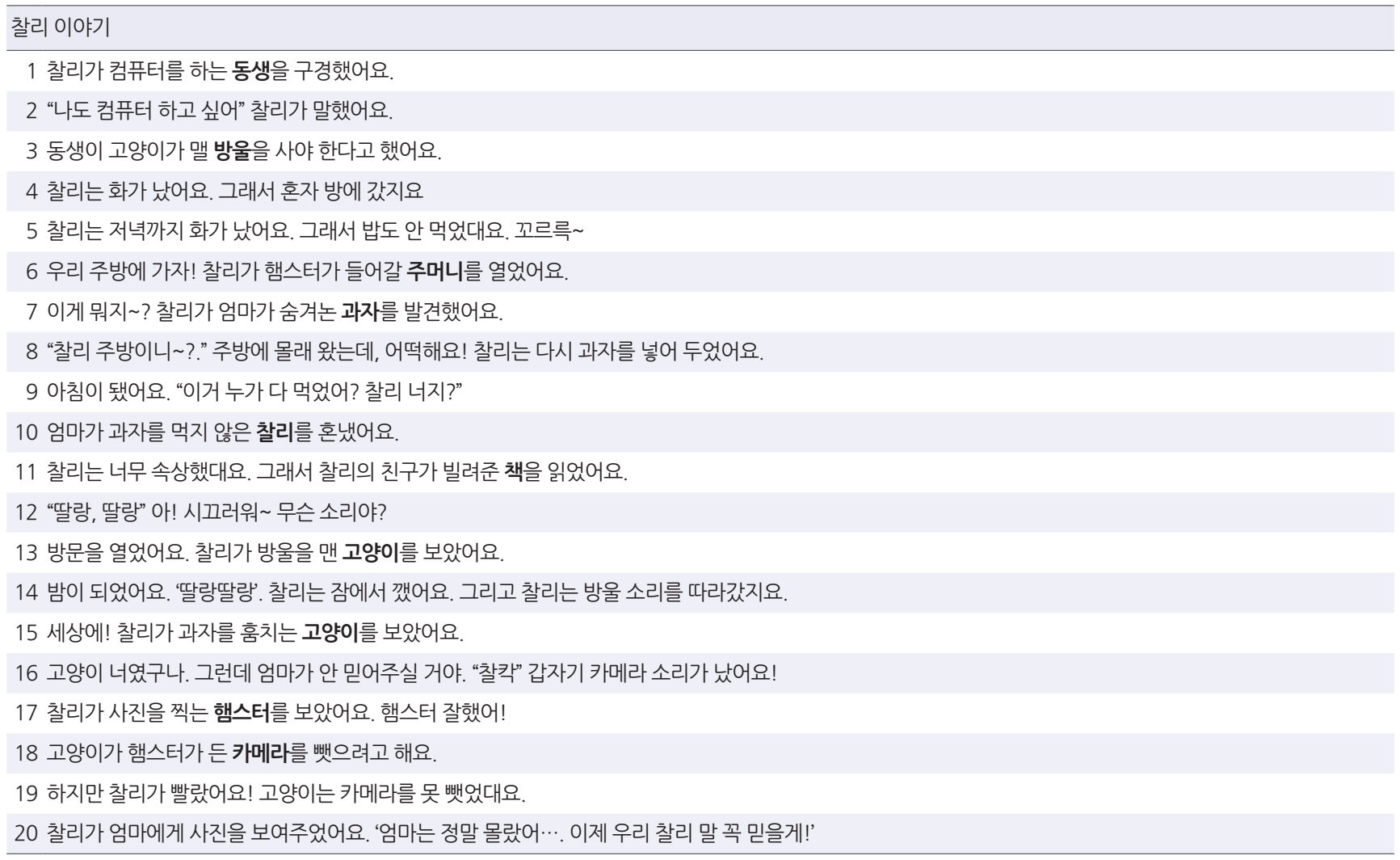


Appendix 2. Story (reference and inference) comprehension question

\begin{tabular}{|c|c|c|c|c|c|}
\hline 참조적 이해 질문 & 정답 예시 & 0 & 1 & 2 & $\begin{array}{c}\text { 아동 반응 } \\
\text { (유의어, 단어를 풀어 설명한 경우=1점) }\end{array}$ \\
\hline 1 누가 컴퓨터를 하고 있었나요? & 동생 & & & & \\
\hline 2 동생이 컴퓨터로 무엇을 사야 한다고 했나요? & 방울 & & & & \\
\hline 3 찰리는 어디에 햄스터를 넣고 주방으로 데리고 갔나요? & 주머니 & & & & \\
\hline 4 엄마가 주방에 무엇을 숨겨 두었나요? & 과자 & & & & \\
\hline 5 엄마는 처음에 누가 과자를 먹었다고 혼냈나요? & 찰리 & & & & \\
\hline 6 찰리의 친구는 찰리에게 무엇을 빌려주었나요? & 책 & & & & \\
\hline 7 찰리의 방 앞에서 방울을 매고 있던 것은 누구였나요? & 고양이 & & & & \\
\hline 8 진짜 과자를 훔친 것은 누구였나요? & 고양이 & & & & \\
\hline 9 과자를 훔친 고양이의 사진을 찍은 것은 누구인가요? & 햄스터 & & & & \\
\hline 10 고양이는 햄스터에게 무엇을 뺏으려고 했나요? & 카메라 & & & & \\
\hline \multicolumn{2}{|l|}{ (2) } & \multicolumn{3}{|c|}{120} & \\
\hline 추론적 이해 질문 & 정답 예시 & 0 & 1 & 2 & $\begin{array}{c}\text { 아동 반응 } \\
\text { (답변이 충분하지 않은 경우=1점) }\end{array}$ \\
\hline 1 찰리는 왜 동생에게 화가 났을까요? & $\begin{array}{l}\text { 2점: 동생이 컴퓨터를 못하게 해서 등 } \\
\text { 1점: 컴퓨터를 안 보여줘서, 동생이 맨날 } \\
\text { 컴퓨터만 해서 등 }\end{array}$ & & & & \\
\hline 2 찰리는 왜 주방에 갔을까요? & $\begin{array}{l}\text { 2점: 저녁을 안 먹어서 배가 고파서 등 } \\
\text { 1점: 꼬르륵 소리가 나서 등 }\end{array}$ & & & & \\
\hline 3 찰리는 왜 과자를 다시 넣어 두었을까요? & $\begin{array}{l}\text { 2점: 엄마한테 혼날까 봐, 엄마한테 들킬까 봐 } \\
\text { 등 } \\
\text { 1점: 엄마가 불러서 등 }\end{array}$ & & & & \\
\hline 4 고양이가 주방으로 갈 때 왜 소리가 났을까요? & $\begin{array}{l}\text { 2점: 고양이 목에 방울이 달려있어서 등 } \\
\text { 1점: 방울은 움직이면 소리가 나서 등 }\end{array}$ & & & & \\
\hline 5 누가 고양이의 목에 방울을 달아주었을까요? & 2점: (찰리의) 동생 & & & & \\
\hline 6 찰리는 왜 엄마에게 카메라를 보여줬을까요? & $\begin{array}{l}\text { 2점: 자기가 과자를 먹지 않았다는 증거를 } \\
\quad \text { 대려고 등 } \\
\text { 1점: 엄마한테 믿어달라고 등 }\end{array}$ & & & & \\
\hline 7 엄마에게 보여준 카메라에는 어떤 사진이 들어있었을까요? & $\begin{array}{l}\text { 2점: 고양이가 과자를 먹는 장면, 고양이가 } \\
\text { 과자를 훔치는 장면 등. } \\
\text { 1점: 고양이 }\end{array}$ & & & & \\
\hline 8 사진을 본 엄마는 어떤 마음이 들었을까요? & $\begin{array}{l}\text { 2점: 미안한 마음 } \\
\text { 1점: 찰리가 하지 않았다 등 }\end{array}$ & & & & \\
\hline 9 과자가 또 없어지면 엄마는 누구를 혼낼까요? & 2점: 고양이 & & & & \\
\hline $\begin{array}{l}10 \text { 고양이가 카메라를 뺏었다면 엄마는 계속 어떻게 생각 } \\
\text { 했을까요? }\end{array}$ & $\begin{array}{l}\text { 2점: 찰리가 과자를 먹었을 것이라고 } \\
\text { 생각한다 등 } \\
\text { 1점: 찰리에게 계속 화가 났다 등 }\end{array}$ & & & & \\
\hline 총점 & & & 120 & & \\
\hline
\end{tabular}




\section{국문초록}

\section{시선 추적 및 집행기능을 통한 단순언어장애 아동의 이야기 이해력 예측연구 송덕진 · 임동선 이화여자대학교 일반대학원 언어병리학과}

배경 및 목적: 이야기 이해 능력은 학령전기 아동의 언어 능력뿐만 아니라 학령기의 학습 능력까지 뒷받침한다. 세 가지 집행기능의 하 위 과제(갱신, 억제, 전환)와 시선추적기를 활용하여 온.오프라인으로 이야기 이해 처리 과정을 분석하고 이야기 이해를 가장 잘 설명할 수 있는 요인이 무엇인지 알아보고자 하였다. 방법: 만 4-6세의 일반 아동 17명, 단순언어장애 아동 11 명이 연구에 참여하였다. 참조 및 추론적 이야기 이해 과제, 시선추적기를 이용한 이야기 처리 과정(평균 시선고정 시간), 집행기능을 대표하는 갱신, 억제, 전환 과제 $(n-$ back, flanker, DCCS)를 통해 두 집단의 차이를 비교하였으며 상관분석을 통해 각 변인들의 연관성을 알아보고 회귀분석을 통해 집행 기능의 하위 요소 및 시선추적기 변수 중 어떠한 변인이 이야기 이해력을 예측해주는지 알아보았다. 결과: 단순언어장애 아동 집단은 참조 및 추론적 이야기 이해와 집행기능의 갱신 기능과 전환 기능에서 일반 아동 집단보다 어려움을 보였으며 이야기 내의 그림자극을 일반 아동 집단보다 짧게 응시하였다. 또한 단순언어장애 아동과 달리 일반 아동은 이야기 이해력과 집행기능의 하위 요소, 평균 시선 고정 시간에서 상관관계를 보였으며 일반 아동의 참조 및 추론적 이해력을 설명하는 공통적인 능력은 갱신 능력이었다. 논의 및 결론: 일반 아동 집단은 단순언어장애 아동 집단 비해 집행기능을 활용하여 이야기를 효율적으로 이해하고 그림책에서 중요한 의미를 갖는 영역에 오랫동안 시선을 응시하여 학습에 도움을 받을 수 있음이 시사된다.

핵심어: 시선추적기, 집행기능, 이야기 이해, 단순언어장애, 학령전기, 담화

본 연구는 2020년 대한민국 과학기술정보통신부와 한국연구재단의 지원을 받아수행된 연구임(NRF-2019R1A2C1007488).

\section{참고문헌}

김영태, 홍경훈, 김경희, 장혜성, 이주연 (2009). 수용·표현어휘력검사(REVT). 서울: 서울장애인종합복지관. 김영태, 성태제, 이윤경 (2003). 취학전 아동의수용언어 및 표현언어 발달척도 (PRES). 서울장애인종합복지관. 김정아, 성지은, 김영태 (2018). 5-6 세 아동의 작업기억 능력과 담화 능력의 관계. 언어치료연구, 27(1), 29-43.

문수백, 변창진 (2003). K-ABC 교육·심리측정도구(K-ABC). 서울: 학지사.

박주혜, 김영욱 (2009). 경도 지적장애아동의 관형절이 포함된 내포문 이해에 관한 연구: 첨가위치, 병행기능 단서를 중심으로. Communication Sciences \& Disorders, 14(4), 456-69.

양윤희, 임동선 (2018). 학령전기 어휘발달지연 및 또래 아동의 어휘습득을 위한 집행기능의 역할. Communication Sciences \& Disorders, 23(1), 43-59. 유지원, 임동선 (2018). 학령기 어휘취약아동 및 또래 아동의 집행기능과 어휘 및 읽기능력과의 관계. Communication Sciences \& Disorders, 23(3), 570-583.

윤소망, 임동선 (2019). 단순언어장애 아동과 정상 발달 아동의 지속주의 능력과 시선추적연구를 통한 빠른우연학습의 관계. Communication Sciences \& Disorders, 24(4), 852-867.

윤주인, 박영신 (2014). 과거와 미래사건의 순서에 대한 추론의 발달과 집행기능 한국심리학회지: 발달, 27(4), 51-74.

윤혜련, 김영태 (2005). 학령기 단순언어장애아동의 이야기 이해특성. Communication Sciences \& Disorders, 10(3), 41-56.

이상언, 임동선 (2018). 상호작용적 책읽기 상황에서 양육자의 질문유형에 따른 어휘발달지연 아동의 정.오반응 비교 연구. Communication Scienc-

es \& Disorders, 23(3), 584-596.

임동선, 박원정, 김신영, 한지윤, 송은, 손진경 (2019). 그림책 읽기에서 일반아동 및 어휘발달지연 아동의 이야기 이해 능력 및 안구 운동 패턴 분석: 시 선추적기 연구. Communication Sciences \& Disorders, 24(2), 299-316. 
천소연, 임동선 (2017). 단어목록 회상을 통한 언어발달지체 아동과 일반아동의 덩이짓기 능력 연구. Communication Sciences \& Disorders, 22(2), 233-244.

한지윤, 임동선 (2018). 부모 보고형 아동 언어 능력 평가도구(KBPR)의 표준화를 위한 예비연구. 언어치료연구, 27(2), 69-84.

Brookshire, R. H. (2014). 신경의사소통장애(제7판, 권미선, 이재홍, 하지완, 황민아 역). 서울: 박학사.

ORCID

송덕진(제1저자, 대학원생 https://orcid.org/0000-0002-7910-1773); 임동선(교신저자, 교수 https://orcid.org/0000-0001-8254-9504) 